\title{
Crédito y mercados financieros en la Península Ibérica a finales de la Edad Media. Producción historiográfica y evoluciones recientes
}

\author{
Credit and financial markets in the Iberian Peninsula at the end of the Middle Ages. Historiographic production \\ and recent developments
}

Antoni Furió

Universitat de València, España

antoni.furio@uv.es

\section{Resumen:}

El artículo examina la trayectoria de los estudios sobre el crédito y los mercados financieros en la Península Ibérica a finales de la Edad Media, desde los primeros trabajos sobre la usura y el préstamo a interés, fundamentalmente judío, en la primera mitad del siglo XX, hasta las líneas de investigación más recientes, que se ramifican en diversas direcciones, desde el marco teórico, doctrinal y legal del mercado del crédito y el estudio de los diferentes instrumentos financieros -préstamo a interés, crédito comercial y bancario, crédito a largo plazo en forma de censales y censos consignativos- a la deuda pública y el crédito privado, especialmente el crédito rural. Todos estos estudios muestran el vigor y la fecundidad de un tema de estudio sustancial, nuclear, que apela a múltiples áreas de conocimiento, desde la historia rural y agraria a la historia urbana, fiscal y financiera. También muestra la vitalidad de una historia económica que sigue siendo más histórica que econométrica, con datos y métodos cuantitativos, pero sin necesidad de imponer lógicas contemporáneas, neoclásicas o neoliberales, a las economías del pasado.

Palabras Clave: Crédito, Usura, Préstamo, Deuda, Finanzas, Europa, Historia.

\section{ABstract:}

The article examines the trajectory of studies on credit and financial markets in the Iberian Peninsula at the end of the Middle Ages, from the first works on usury and interest-bearing loans, mainly Jewish, in the first half of the 20th century, to the most recent lines of research, which branch out in different directions, from the theoretical, doctrinal and legal framework of the credit market and the study of the different financial instruments -interest loans, commercial and bank credit, long-term credit in the form of censales and censos consignativos- to public debt and private credit, especially rural credit. All these studies show the vigor and fruitfulness of a substantial, nuclear, subject of study that appeals to multiple areas of knowledge, from rural and agrarian history to urban, fiscal and financial history. It also shows the vitality of an economic history that continues to be more historical than econometric, with quantitative data and methods, but without the need to impose contemporary, neoclassical or neoliberal, logics on the economies of the past.

KEYWORDS: Credit, Usury, Loan, Debt, Finances, Europe, History.

La historia del crédito y los mercados financieros en la Edad Media ha sido tan tardía en la historiografía ibérica como lo ha sido, en general, la historia económica. De hecho, durante mucho tiempo, la España franquista, incluida la académica, no dejaba de mirar con reticencia todo lo relacionado con el estudio de la economía, porque se temía que pudiese convertirse en una puerta de entrada al marxismo, y aunque desde 1943 existía en la Universidad Complutense de Madrid una Facultad de Ciencias Políticas y Económicas, en la que la mayoría de profesores procedían de la Facultad de Derecho, la Facultad de Ciencias Económicas y Empresariales no se creó hasta 1971. Lo mismo sucedió en la Universidad de Barcelona, donde la Facultad de Ciencias Políticas, Económicas y Comerciales, fundada en 1953, solo pasó a denominarse Facultad de Ciencias Económicas y Empresariales en 1972. Sin duda, tras el impulso de las nuevas facultades de economía a principios de los setenta estaban el éxito del Plan de Estabilización de 1959, que acababa con la política de autarquía de la larga posguerra, el desarrollo económico y social de los años sesenta y la creciente influencia de los tecnócratas del Opus Dei en los últimos gobiernos del franquismo. Paralelamente se produjo una profunda renovación en los estudios de historia económica gracias a grandes empresas historiográficas como 
la Historia social y económica de España y América, dirigida por Jaume Vicens Vives y publicada en 1957, y el Manual de historia económica de España, publicado dos años después por el propio Vicens en colaboración con su discípulo Jordi Nadal. Vicens también resultaría clave en la introducción de los postulados de la escuela francesa de los Annales en la historiografía española, como lo sería igualmente el hispanista Pierre Vilar en su doble condición de marxista y "annalista” (Vázquez de Prada, 1990; Ruiz Torres, 2002). La historia económica gozaría de un gran prestigio en España desde finales de los cincuenta, con las obras ya citadas de Vicens Vives y, poco después, la Catalogne dans l'Espagne moderne (1962) de Vilar, hasta principios de los ochenta, con la celebración del Primer Congreso de Historia Económica de España en 1972, impulsado por Jordi Nadal y Gabriel Tortella, la creación ese mismo año de la Asociación Española de Historia Económica y la fundación de la Revista de Historia Económica en 1983. Hasta entonces apenas había diferencias entre los historiadores económicos formados en facultades de historia y los formados en facultades de economía, en parte porque la mayoría procedían del campo de la historia y en parte también porque unos y otros compartían a grandes rasgos los mismos presupuestos teóricos y metodológicos, en los que se combinaban las influencias annalista, marxista y anglosajona. Sin embargo, en los últimos casi cuarenta años se han ido desarrollando y afianzando dos tendencias opuestas que han alterado profundamente aquel espacio historiográfico común y han reconfigurado por completo la disciplina.

Por un lado, la historia económica se ha visto desplazada de su posición dominante en los estudios históricos por el llamado giro lingüístico y la historia cultural, con sus propuestas de retorno al sujeto, al individuo e incluso al relato y la narración como forma de escritura de la historia. Una historia, en todo caso, más interesada por las representaciones que por la realidad social. Esta nueva historia cultural, muy influida por la lingüística y la antropología, no solo ha sustituido la economía por la cultura como objeto preferente de estudio, sino que propugna al mismo tiempo un retorno a la narración histórica en detrimento de los grandes paradigmas teóricos y metodológicos que habían dominado la historiografía de las décadas anteriores. Es decir, no se trata solo de un desplazamiento temático, sino también de una profunda transformación en la manera de concebir y escribir la historia, cada vez más alejada del análisis cuantitativo y estadístico, sustituido por una aproximación de tipo más cualitativo e incluso microhistórico, centrado a menudo en casos individuales (Sobre el giro lingüístico y el retorno de la narrativa, véase Stone, 1979 y 1991; Aurell, 2004 y 2005; Burke, 2010; Poirrier, 2012).

Por otro lado, la paulatina desaparición de la historia económica de los departamentos de historia ha ido cediendo el estudio del pasado de la vida económica a los economistas, los cuales se muestran más interesados en aplicar teorías y técnicas propias de la economía contemporánea, y en particular de la teoría neoclásica, que en la comprensión amplia y compleja de la historia de la vida económica. Hace cincuenta años la mayoría de los historiadores económicos eran de formación histórica; hoy, en cambio, lo son de formación económica, en facultades y departamentos de economía en los que se ha ido imponiendo, primero, la llamada new economic history y, después, la cliometría y la nueva economía institucional, que han convertido a la historia económica en una econometría retrospectiva, en una suerte de aplicación de los modelos estadísticos econométricos al estudio del pasado, basada fundamentalmente en un razonamiento económico matemático, o en una rama de la economía neoinstitucionalista. En su crítica a esta nueva forma, hoy hegemónica, de entender la historia económica, y en particular a la cliometría, algunos autores no dudan en calificarla de quiebra intelectual (intellectual bankruptcy), en la medida que la disciplina ha dejado de ser una forma de historia para convertirse en un sub-campo de la economía, en una economía aplicada al pasado, en este caso en una economía neoclásica o neoinstitucionalista. Se mire como se mire, lo cierto es que las concepciones y procedimientos de la economía contemporánea han acabado por colonizar y distorsionar la historia económica. Y ello ha tenido una doble consecuencia, tanto metodológica como intelectual y política. En el primer caso, el problema surge de la sustitución del método inductivo propio de la investigación histórica, a partir de las fuentes disponibles sobre la vida económica, por la deducción a partir de las teorías económicas contemporáneas. A los cliómetras se les suele acusar, con razón, de ser poco cuidadosos en el uso de fuentes 
primarias, cuando no prescinden totalmente de ellas, y de reducir la historia económica a mero campo de experimentación de la teoría económica, hasta el punto incluso de llegar a analizar las economías antiguas, premodernas, no tanto de manera empírica, a través del examen de las fuentes documentales del período, sino mediante la deducción e inferencia, con carácter retrospectivo, es decir, mediante regresiones, de los principios de la moderna economía neoclásica. Quizá uno de los ejemplos más representativos de esta manera de hacer historia económica, de esta econometría retrospectiva, sea el cálculo del Producto Interior Bruto para periodos preestadísticos, basado más en inferencias y regresiones que en un análisis concienzudo de las fuentes documentales coetáneas. No se trata solo de un problema metodológico. A los cliómetras también se les reprocha su agenda política e ideológica, de clara defensa de la economía neoliberal, a menudo oculta tras la aparente neutralidad de deducciones matemáticas y estadísticas (Para una crítica de la nueva historia económica véase Boldizzoni, 2013; véase también la respuesta de McCloskey, 2013, que alude al subtítulo de la edición inglesa del libro de Boldizzoni).

Lo cierto es que para muchos historiadores económicos, sobre todo los que ejercen en facultades de economía, todo lo anterior a 1800 es pura prehistoria, y cuando se aventuran más allá, lo hacen provistos más de sus ecuaciones matemáticas y curvas logarítmicas que de un conocimiento preciso de las fuentes del periodo histórico que pretenden estudiar. Por otra parte, al estar convencidos de la universalidad de la teoría económica, tratan de imponer su lógica, su racionalidad, a los distintos sistemas económicos que se han sucedido, dificultando todavía más su comprensión histórica. Entre las formas narrativas de la historia y su reducción a ejercicios empíricos de economía aplicada, la historia económica, que no puede dejar de ser al mismo tiempo historia social y cultural, que no rechaza tampoco las aportaciones de la antropología y la sociología económicas, ha tenido que encontrar una vía intermedia, que, por lo que aquí nos atañe, se ha mostrado muy fecunda en el estudio del crédito y los mercados financieros.

Volviendo de nuevo la vista atrás, mientras los estudios sobre el crédito en la Edad Media remontan a finales del siglo XIX y principios del XX en las historiografías francesa, alemana, inglesa e italiana (Rebouis, 1881; Speyer, 1883; Lionti, 1884; Des Marez, 1898; Génestal, 1901; Legras, 1911; Postan, 1927-28; Guerrieri, 1900; Salvioli, 1906), en España hay que esperar a los años treinta y cuarenta para encontrar los primeros trabajos sobre el tema (el más antiguo que he sabido encontrar es un artículo de Cantera, 1931). El retraso se compensa con la fuerza con que irrumpe: por un lado, con la revista Moneda y crédito, fundada en 1942 como una especie de contrapeso liberal a las tesis oficiales del primer franquismo, marcado en lo económico por el intervencionismo y la autarquía (Villagrasa, 2015; la revista, en la que publicaron los más prestigiosos economistas de la época, supuso también una ventana al pensamiento económico internacional en los momentos más oscuros de la primera etapa del franquismo) y, por otro, con la potente obra de Ramón Carande sobre Carlos Vy sus banqueros, cuyo primer volumen, publicado por la Revista de Occidente, apareció en $1943 .^{1}$ Jurista de formación, como lo eran también los primeros historiadores que empezaban a ocuparse de la economía, Carande, muy vinculado al historiador del derecho Eduardo de Hinojosa, al filósofo y pedagogo Francisco Giner de los Ríos y al economista Antonio Flores de Lemus, fue, al decir de Ricardo García Cárcel, "un economista que creyó en los hombres más que en los números, en los banqueros más que en la hacienda". La suya era "una economía sin números, ni gráficos, ni grandes cuadros estadísticos" que, a pesar de usar el lenguaje de la historia narrativa tradicional, destacaba en el erial de un panorama historiográfico dominado por la loa al glorioso pasado imperial y los estériles debates metafísicos en torno al "ser de España” (García Cárcel, 1988). Quizá por ello, y también, sin duda alguna, por la originalidad y la calidad de sus planteamientos, totalmente atípicos en el contexto de la época, Carlos $V$ y sus banqueros constituye una obra excepcional en la historiografía española de la posguerra, cuya trascendencia fue mucho más allá de los límites de la historia económica.

Como Carande, la mayoría de los historiadores económicos de estos años, tanto de España como de Portugal, llegaron a la economía desde el derecho, su perspectiva era fundamentalmente jurídica e institucional y su interés se centraba principalmente en la regulación legal de la usura (un buen ejemplo de 
ello es el artículo de Oliveira Campos, 1952). Era algo similar a lo que estaba sucediendo también en Italia, como muestran, entre otros, los trabajos de Armando Sapori, Gino Luzzatto y Ovidio Capitani, centrados en la doctrina escolástica sobre la usura, su reglamentación y los tipos de interés en diversas ciudades de la Italia central y septentrional (Sapori, 1929; Coniglio, 1952; Becker, 1956; Luzzatto, 1958; Capitani, 1958 y 1965; Giammanco, 1959), mientras que en Francia, Bélgica e Inglaterra, aun sin dejar del todo la perspectiva jurídica y teológica (Le Bras, 1923-1946; McLaughlin, 1939 y 1940; Woollen, 1940; Taeusch, 1942; Rabinowitz, 1944; Nelson, 1949; Noonan, 1957; Pacaut, 1963; De Roover, 1964; Sicard, 1965), la orientación era más económica, con particular atención al crédito comercial y bancario, las letras de cambio, la deuda pública y las finanzas reales (Sayous, 1932, 1933 y 1934a; Doucet, 1934; Dhondt, 1941; De Roover, 1942, antecedente del gran libro de 1948; Coryn, 1945; Boyer, 1948; Fryde, 1949; De Malafosse, 1951; Grunzweig, 1962; Bergier, 1962; Fryde, 1964). La única excepción que conozco para la España de estos años es un artículo del entonces joven licenciado en económicas Ramón Ramia de Cap (1948) sobre el crédito en la baja Edad Media. En realidad, los primeros trabajos sobre el crédito bajomedieval desde una perspectiva propiamente económica fueron obra de hispanistas franceses y anglosajones, como André-Emile Sayous, que empezó a estudiar desde principios de los años treinta los métodos comerciales y la vida económica de la Barcelona de los siglos XIV y $\mathrm{XV}$, a partir fundamentalmente de los ricos fondos notariales de la ciudad, y dedicó un artículo al origen de la letra de cambio (Sayous, 1933 y 1934a); Abbot P. Usher, especialista en la banca medieval y quien por la misma época escribía sobre el depósito bancario en Barcelona entre 1300 y 1700 (Usher, 1931-32); y, sobre todo, Yvan Roustit, el primero en estudiar los orígenes de la deuda pública en la capital catalana (Roustit, 1954), y Claude Carrère, autora de una tesis doctoral sobre la vida económica de Barcelona, en la que se examinaba el importante papel que tuvieron los títulos de deuda entre las inversiones de los mercaderes y hombres de negocios barceloneses (Carrère, 1967). Aunque la mayoría de los hispanistas se centraron en Cataluña y particularmente en Barcelona, otros, como Henri Lapeyre -autor de diversos trabajos conjuntos con Ramón Carande y, sobre todo, Felipe Ruiz Martín- y Bartolomé Bennassar estudiaron las prácticas bancarias, los censos perpetuos y las finanzas reales en Castilla, la Corona de Aragón y el reino de Valencia (Lapeyre, 1949, 1955, 1961, 1968, 1969 y 1973; Carande y Lapeyre, 1959 Bennassar, 1960). ${ }^{2}$

Fueron de nuevo, sin embargo, los historiadores del derecho quienes dieron un nuevo impulso a los estudios sobre el crédito medieval al llamar la atención sobre un instrumento de crédito a largo plazo vitalicio o perpetuo-, el censal -violari en su modalidad vitalicia- en la Corona de Aragón y el censo consignativo y los juros en Castilla y Portugal. Tanto en Portugal como en España los primeros estudios sobre esta nueva forma de crédito, que permitía poner en circulación una masa monetaria mayor que los préstamos usurarios y que, en el caso de las haciendas públicas, están en el origen de un nuevo sistema fiscal y financiero, datan de principios de los años sesenta y son obra de eminentes historiadores del derecho y la economía como el portugués Mário Costa (1961), el zamorano Antonio Matilla Tascón (1952; aunque casi una década anterior, no es una obra dedicada expresamente al estudio de los juros, sino a su utilización durante el reinado de los Reyes Católicos), y los valencianos Arcadi García Sanz (1961 y 1988), que había estudiado ya con anterioridad otros instrumentos crediticios y bancarios (1955-57, 1957 y 1958-60), y Álvaro Castillo Pintado (1963). ${ }^{3}$ Entonces no se sabía, porque se pensaba que estos instrumentos de crédito eran propios de la Península Ibérica, pero en realidad eran muy similares a las rentes constituées y otras formas de renten y annuities que estaban siendo estudiadas para la Francia medieval y otros países desde hacía años (Lefebvre, 1914; Gessler, 1928; Petot, 1928; Moeder, 1953; Dubled, 1955; Ourliac, 1960; Fournial, 1963; Schnapper, 1957 y 1965; Platelle, 1966; Alibart, 1969; Sadourny, 1971; Baum, 1985; Necoechea, 1989; sobre las renten en los Países Bajos, Tracy, 1985). De hecho, sus orígenes parecen remontarse al norte de Francia y los Países Bajos en el siglo XIII o incluso a la Normandía de finales del XII, en donde habría evolucionado desde el censo enfitéutico para convertirse en una de las principales inversiones crediticias tanto de los ricos burgueses de las ciudades septentrionales como de monasterios, abadías y otros establecimientos eclesiásticos (Legras, 1911; Andreau, Béaur y Grenier, 2006; Zuijderduijn, 2009). 
En las décadas siguientes, desde principios de los sesenta a principios de los ochenta, los estudios sobre el crédito se centraron en la doctrina eclesiástica sobre la usura, su regulación legal, el préstamo a interés y en particular el judío, y la difusión de los censales y censos consignativos y sus consecuencias económicas y sociales. En cuanto a la usura, son numerosos los trabajos publicados en esta época sobre la condena eclesiástica y la prohibición legal, especialmente a partir del siglo XIII, lo que impulsó la difusión de otras formas de crédito, en particular censales y juros, cuya licitud, aunque también cuestionada, no era directamente impugnada por la Iglesia (Villegas, 1962; Benito Ruano, 1970; López Elum, 1971; Oliván, 1977; Clavero, 1977; Hernando, 1981; Cantera Montenegro, 1982; Ruiz Gómez, 1987; Herrera, 1987; Matés y Tirapu, 1993; Hernández Minano, 1994-95; Romano, 1996). Por otra parte, la usura, al estar condenada por la Iglesia y prohibida por la ley, se vinculaba sobre todo al préstamo judío, que quedaba al margen de las interdicciones, aunque la documentación dejaba bien clara la participación en todo momento de prestamistas cristianos en las inversiones crediticias. Tanto si sus motivaciones se limitaban a obtener el máximo rédito posible, en forma de altos intereses, como si formaban parte de una estrategia de conquista territorial, esto es, de apropiarse de las tierras de los deudores aprovechando sus dificultades para reembolsar los préstamos obtenidos. De hecho, las primeras menciones al crédito rural remontan al renovo, una forma de préstamo a interés documentada en los siglos X y XI en el reino, primero, de Asturias y, posteriormente, de León, estudiada por Luis García de Valdeavellano. El renovo tenía una doble dimensión, como instrumento de crédito y como mecanismo de expropiación del campesinado. Por un lado designaba los préstamos concedidos por los grandes propietarios y los monasterios a los campesinos, generalmente en especie (cereales, vino y animales) y garantizados por los frutos de la propiedad cedida en prenda o por la misma propiedad. Pero si los campesinos no podían retornar las deudas, habían de ceder sus tierras a los acreedores, contribuyendo así a la extensión del gran dominio y a la degradación paralela de los alodios campesinos. A lo largo del siglo XII, sin embargo, y a medida que se desarrollaba la economía monetaria, este tipo de préstamo en especie fue desapareciendo, sustituido por los préstamos a interés en metálico (García de Valdeavellano, 1973).

Entre los préstamos a interés destacan en primer lugar los concedidos por judíos, sobre todo tras la condena y prohibición de la usura a los cristianos. Muchos de los estudios de esta época, de la década de los sesenta a la de los ochenta, están dedicados al préstamo judío, el asiento preferentemente urbano de los prestamistas, la obligación de estos de jurar e incluso registrarse ante las autoridades cristianas para poder conceder préstamos, el radio de alcance de los créditos, el carácter rural de la clientela, los tipos de interés, etc., tanto en Navarra y Castilla como en Cataluña y el reino de Valencia (García Sanz, 1961-63; Altisent, 1967; Ladero, 1975; Magdalena Nom de Déu, 1977; Carrasco, 1980, 1982, 1986a y 1986b; García, 1982; Piles, 1984; Hinojosa, 1985; Hurtado, 1987; Romano, 1988; Magdalena Nom de Déu, Casanovas, Castells y García, 1990). Tres libros importantes sobre el pensamiento económico en la Edad Media, la reprobación de la usura y la difusión de los censales y censos consignativos para eludirla fueron los de Marjorie Grice-Hutchinson (1982), una economista británica especializada sobre todo en la Escuela de Salamanca, pero también en el pensamiento escolástico medieval, Mariano Peset (1982) ${ }^{4}$ y Bartolomé Clavero (1985), dos prestigiosos historiadores del derecho cuyos libros reunían artículos publicados con anterioridad por ambos autores sobre la significación económica y social de los censos consignativos. Insatisfecho con las interpretaciones dadas hasta el momento sobre la usura y los censos, en clave netamente weberiana, Clavero proponía descubrir la lógica o "paradigma social" oculta tras el diferente tratamiento que daba la Iglesia a la usura y a la renta, cuando en realidad ambas suponían un mecanismo de explotación. Pero mientras que la Iglesia condenaba el "interés" o beneficio en tanto que, al encarnar las "relaciones de mercado", amenazaba los fundamentos mismos de la institución eclesial y de la sociedad feudal, toleraba la renta, el censo consignativo, en realidad un préstamo encubierto, en tanto que expresión de las "relaciones señoriales". Con la prohibición de la usura, esto es, del beneficio, se evitaba, según Clavero, la introducción de capital de la burguesía en el campo. En el segundo capítulo el autor analiza la evolución del censo consignativo, nacido del enfitéutico, como alternativa a la usura, que, al ser estigmatizada y prohibida a los cristianos, es abandonada a los judíos; y en el tercero, examina el esfuerzo 
de los grandes juristas y canonistas castellanos del siglo XVI por subordinar políticamente y canónicamente el mercado y la finanza al régimen señorial y a la renta territorial. ${ }^{5}$ Por su parte, Mariano Peset, que, como Clavero, ve el censo consignativo a la vez como forma de préstamo encubierta para eludir la prohibición de la usura y como mecanismo de extracción de las rentas campesinas, muestra su gran difusión en la época moderna y en particular cómo habían contribuido a drenar el campo en beneficio de las potentes clases ciudadanas, la nobleza y el clero, hasta el punto de que en algunas haciendas señoriales los censales generaban mayores ingresos que los censos enfitéuticos. El sistema solo quebrará en el siglo XVIII, con la reducción de la tasa de interés impuesta por los Borbones. ${ }^{6}$

Desde el campo de la historia económica la visión era mucho más pesimista, tanto respecto al préstamo judío como a las consecuencias de la inversión y el endeudamiento censalista. En el primer caso, un cierto prejuicio historiográfico relegaba el crédito a un asunto de judíos o de mercaderes extranjeros, los únicos que dominaban el manejo del dinero. El mismo Vicens Vives, en su influyente manual de 1959, no dudaba en afirmar que la sociedad castellana bajomedieval era "ambiciosa y poco dada al trabajo", amante del lujo y cuya "burguesía" fue "incapaz de crear bancos y depósitos bancarios", por lo que los odiados judíos eran los únicos que "sabían el valor del dinero en Castilla". 7 Por su parte, en su extraordinaria obra sobre Cataluña en la época moderna, Pierre Vilar se mostraba muy crítico con la difusión del sistema censalista en los siglos finales de la Edad Media, no solo por la escalada de la deuda pública que había comportado, sino también por haber sustituido la inversión productiva por la indolencia rentista. En su opinión, las capas burguesas del Principado habían acabado utilizando el nuevo sistema de rentas "de manera més segura que audaç, més parasitària que productiva”, lo que conllevaría finalmente a la "pèrdua de l'esperit d'empresa en benefici de l'esperit rendista" (1979, pp. 218-219). En cierto modo, la interpretación de Vilar recuerda las tesis de Fernand Braudel sobre la "trahison de la bourgeoisie" (1982, v. 2, p. 68), y también las de Vicens Vives sobre "el estancamiento mental de la burguesía 'honrada' del Cuatrocientos". ${ }^{8}$ Sin embargo, y con independencia de si el crédito censalista pudo contribuir a la decadencia económica de Cataluña en el siglo XV, y con independencia incluso de si existió realmente tal decadencia, más allá de los años de la guerra civil, lo cierto es que no se produjo una conversión masiva de mercaderes en censalistas, sino que, como ya mostró Claude Carrère en su tesis sobre Barcelona, las compras de títulos de deuda alternaban en las agendas de los hombres de negocios con otras inversiones más arriesgadas y más lucrativas, mientras que los censales, menos rentables, ofrecían mayor seguridad. No obstante, véase también sobre esta cuestión, además de la obra ya citada de Carrère (1967), el libro de Aurell (1996).

Con todo, la difusión del sistema censalista y la extensión de la deuda fueron enjuiciadas de manera muy crítica por los historiadores catalanes, mallorquines y valencianos de los años setenta, que resaltaron tanto la sangría que representaba para las arcas municipales como su carácter improductivo para la economía en general. Álvaro Santamaría, Jaume Sobrequés, Ricardo García Cárcel y Ernest Belenguer denostaron un sistema que, en su opinión, acabaría por ahogar el desarrollo económico apuntado en los últimos siglos medievales, comprometiendo seriamente los progresos del capitalismo comercial, fomentando el rentismo y la inversión no productiva, exacerbando las tensiones entre los grupos sociales -como ocurrió durante la revuelta de las Germanías, a principios del siglo XVI- y reforzando en definitiva la propiedad feudal de la tierra, a pesar de las múltiples transferencias de dominio de unos señores a otros, impuesta o facilitada por el endeudamiento censal de varios señoríos, especialmente en el área valenciana (Santamaría, 1972-73; Sobrequés, 1973; García Cárcel, 1975 y 1976; Belenguer, 1976; aunque unos años posterior, véase también Pastor Zapata, 1984). Una caracterización que coincidía, en bastantes puntos, con la ofrecida por Bartolomé Bennassar para el Valladolid del siglo XVI (1967, p. 272).

Tras los trabajos más o menos puntuales sobre el préstamo judío, los aspectos jurídicos e institucionales de los instrumentos de crédito, a cargo fundamentalmente de historiadores del derecho, su licitud canónica y su regulación legal y la valoración más bien crítica de su significación económica y social que caracterizaron las décadas centrales del siglo XX y hasta bien entrados los ochenta, los últimos treinta años han conocido una 
verdadera eclosión de estudios sobre el crédito y el mercado de capitales en la Edad Media. Estos estudios, que han propiciado la aparición de sucesivas síntesis generales o regionales (Ladero Quesada, 1990-91; Furió, 1995; Sánchez Martínez, 2006b y 2007), han puesto de manifiesto la omnipresencia del crédito en la economía medieval, tanto en el campo como en la ciudad y en el mundo del comercio, tanto entre nobles e instituciones eclesiásticas como entre burgueses y campesinos, tanto para asegurar el consumo como para facilitar la inversión productiva, y tanto para garantizarse unas rentas seguras como para constituir dotes de hijas e hijos segundones, fundar capellanías y beneficios eclesiásticos y, con todo ello, movilizar una masa monetaria no solo superior a la realmente en circulación en forma de moneda sino también a la captada solo por el préstamo a interés, considerado durante mucho tiempo el único o el más importante instrumento de crédito. También han demostrado que había muchísimas formas de crédito y que los préstamos usurarios, los depósitos y las comandas comerciales y, más tarde, los censales y los juros no eran más que la parte superior y visible del inmenso iceberg del crédito, de la que también formaban parte las obligaciones, los reconocimientos de deuda y las compras a plazo con el pago diferido. Era lo que podemos considerar el crédito formal, esto es, el crédito formalizado y registrado ante notario o ante el juez (en el caso de la Corona de Aragón, para las obligaciones y compras a plazo). Pero por debajo de la línea de flotación del iceberg queda sumergida toda una parte importante, el llamado crédito informal, oral, no registrado documentalmente, del que desconocemos su extensión y profundidad, justamente por no dejar traza escrita, ni siquiera en los procesos judiciales por morosidad o insolvencia.

Por razones de espacio, me limitaré en las páginas siguientes a esbozar las cuatro grandes líneas en las que se ha desarrollado el estudio del crédito y los mercados financieros en los últimos años. En primer lugar está la noción misma de mercado - mercado del crédito, mercado del dinero, mercado de capitales, mercados financieros-, uno de los tres factores de producción empleados para producir bienes y servicios, utilizados por la economía clásica, y al que se podría añadir también el mercado de productos. Los mercados de capitales, en plural, tanto regionales como internacionales, y su conexión con los otros mercados, el de la tierra y el del trabajo, han conocido un importante desarrollo con las obras de C. Jaco Zuijderduijn (2009), Bas J. P. van Bavel (2010a 2010b y 2016) y, desde una perspectiva neoinstitucionalista, Stephan R. Epstein (2009), que ha tenido también su reflejo en la historiografía ibérica, que en unos casos ha relacionado el crédito con el mercado de la tierra (Borrero, 2004; Furió, 2004; véase también la visión más general que dedicó al tema Astarita,1992) y, en otros, se ha centrado en el mercado internacional de capitales (Igual, 2018) o en los mercados del dinero locales y regionales (hay que citar en primer lugar, aunque exceda del marco cronológico de la Edad Media, el artículo de Castillo, 1970, al que han seguido más recientemente, entre otros, Carrasco, 2002, y Laliena e Iranzo, 2016). También se ha avanzado en un mejor conocimiento del pensamiento económico medieval, y en particular su renovación por los teólogos franciscanos y su progresiva legitimación, primero, de la actividad mercantil y, después, de los censos consignativos, en una línea próxima a la desarrollada por Giacomo Todeschini, quien, contra la teoría de Max Weber de un capitalismo vinculado al espíritu del protestantismo, encuentra las raíces del pensamiento económico moderno en los escritos teológicos del período medieval (Todeschini, 1989 y 2004; véase también Todeschini, Quaglioni y Varanini, 2005). En concreto se han editado y estudiado diversos tratados de usura, como el de Francesc Eiximenis (Hernando, 1983 y 1984), y las controversias sobre la licitud de los censales, sobre todo entre franciscanos y dominicos (Hernando, 1989a, 1989b, 1992 y 2007). Josep Hernando ha sido el verdadero impulsor de estos estudios, centrados principalmente en el ámbito catalán (1981, 1982-83 y 2000; véase también Llop Catalá, 1988 y 1995), aunque también otros autores se han ocupado del tema para Castilla y Navarra (Pereira, 2001; Colombo, 2003-06; Carrasco, 2005; González Ferrando, 2012; Arquero, 2014-15).

En una segunda línea, menos doctrinal y más centrada en formas concretas de crédito, podemos incluir los trabajos que han continuado ampliando nuestros conocimientos sobre el préstamo a interés -a corto plazo-, mostrando que no se trataba de una actividad crediticia practicada solo por judíos, sino también por cristianos, e incluso de cristianos a judíos (Carrete y Moreno, 1995); el crédito comercial y bancario y 
los censales y juros -crédito a más largo plazo. En el primer caso, se han editado diversos Liber iudeorum (Llop i Jordana, 1998; Aleixandre, 2004), que recogían la actividad crediticia de los judíos catalanes y se han publicado numerosos estudios puntuales sobre Galicia y Portugal (De Antonio, 2004, 2006 y 2016), Castilla (Cantera Montenegro, 1999; Crespo, 2002), Navarra (Carrasco, 2008, 2009, 2015 y2019), Cataluña (Rich, 1991; Fernàndez Cuadrench, 1998; Denjean, 1998, 2006, 2009, 2010, 2011 y 2017; Mateu, 2001; Aleixandre, 2009; Muntané Santiveri, 2013 y 2016), Mallorca (Maíz, 2009), el País Valenciano (Además de los numerosos estudios dedicados al tema por José R. Hinojosa Montalvo, el último de los cuales, 2009, y por José R. Magdalena Nom de Déu, entre ellos, 1988, véase el número monográfico de la Revista d’história medieval, 4, 1993, con artículos de Riera, Mira y Furió, así como la tesis doctoral de Aleixandre, 2015) y la península en su conjunto (Romano, 1994). En cuanto al crédito comercial y bancario, los estudios han abordado la intermediación financiera de los cambistas, los agentes de la banca internacional, las letras de cambio y los giros dinerarios y los intentos de creación de una banca propia (García Marsilla, 1995; Conde, 1997; Bernal, 2000, con numerosos trabajos sobre las actividades financieras durante la Edad Media; Navarro e Igual, 2001 y 2002; Feliu, 2007 y 2016; Mercader y Cateura, 2015; Miquel, 2019, y muy en particular los numerosos artículos que David Igual ha dedicado al tema en los últimos veinte años, entre los cuales, 2000, 2003, 2014a, 2014b, 2016 y 2018. Sobre banqueros y financieros trata también el libro editado por Alloza, Fernández y García Guerra -2012-, con contribuciones de Jordi Morelló y Albert Reixach sobre financieros catalanes y de Elena García Guerra sobre el mercader-banquero castellano en el siglo XVI). Finalmente, por lo que respecta al crédito a largo plazo, en forma de venta de censos y juros, se han publicado también numerosos trabajos en estos últimos veinte o veinticinco años, que han destacado sobre todo las estrategias inversoras de los censalistas y el papel que jugaba este tipo de crédito en las haciendas señoriales, tanto entre los ingresos como entre los pagos (Cervantes, 1993 y 1996; Ackerley, 1994; Pereira, 1995; Garcia-Oliver, 1997; Rubio Manuel, 2003; Picazo, 2007; Ortega, 2010; Rubio Martínez, 2010; Tello, 2015; Torras, 2018). Más allá de la enumeración profusa de estudios, por otra parte ilustrativa de la abundante producción historiográfica sobre la materia, conviene, no obstante, destacar aquellos estudios que, yendo un poco más allá del análisis concreto de su área territorial o de un instrumento de crédito particular, han procurado esbozar un marco cronológico más amplio, en el que han descrito tanto las diversas fórmulas crediticias disponibles como su respectiva posición hegemónica en cada momento. Me refiero a dos artículos de Guillermo Castán Lanaspa (1983) y Pablo Lara Izquierdo (1983) sobre el área castellano-leonesa y la aragonesa, respectivamente, y, sobre todo, a la tesis doctoral de Juan Vicente García Marsilla sobre la formación del mercado de crédito valenciano (García Marsilla, 2002. Sobre el caso valenciano, yo mismo había ofrecido un primer esbozo en Furió, 1993). A partir fundamentalmente de documentación monástica y catedralicia, Castán examina las distintas formas de crédito presentes en el mundo rural castellano-leonés, desde el préstamo a interés -practicado tanto por judíos como por cristianos, con la diferencia de que los primeros actuaban básicamente en las ciudades, mientras los segundos, señores feudales principalmente, prestaban a campesinos, generalmente sus propios vasallos- hasta las más diversas fórmulas crediticias en las que el interés queda disimulado bajo la forma de contratos de compraventa, arrendamientos con pago adelantado, ventas a plazo y otras, para concluir que el recurso al crédito, y el subsiguiente endeudamiento, era un fenómeno ampliamente generalizado, que afectaba a todas las clases y capas sociales, aunque entre los prestamistas predominaban los señores, laicos y eclesiásticos, siendo más rara la participación de burgueses y judíos. Por su parte, Lara recurre a los registros notariales de Zaragoza para analizar las diversas formas de crédito documentadas en el territorio aragonés, entre las que destaca sobre todo, junto a los préstamos usurarios y los censales, la comanda, un tipo de contrato que podía albergar a su vez toda una variedad de modalidades crediticias, desde las compras a pago anticipado y las ventas con pago diferido a los pagos anticipados por servicios a prestar, los cobros diferidos por servicios prestados, los préstamos comerciales y los préstamos de consumo. Además del análisis formal, ilustrado con una amplia casuística, Lara estudia la incidencia de las operaciones crediticias en las estructuras socioeconómicas urbanas y en la proyección de la ciudad sobre el medio rural circundante. De 
manera similar, García Marsilla documenta y considera los distintos tipos de préstamo que concurrían en la Valencia bajomedieval, "una sociedad que vive a crédito", desde el préstamo a corto plazo (mutuum) al contrato de depósito o comanda, las compraventas a plazos y las obligaciones, la usura judía y la banca y los contratos de cambio, para pasar a continuación a examinar los orígenes, el desarrollo y la consolidación del crédito a largo plazo, el censal, objeto central de la tesis. García Marsilla puede así fijar la aparición de este nuevo instrumento de crédito, derivado del censo enfitéutico, a finales del siglo XIII y principios del XIV, cuando el préstamo a interés era todavía hegemónico, para difundirse a lo largo del Trescientos y convertirse en mayoritario a partir del último cuarto de esta centuria, gracias sobre todo a la superación de las trabas legales y canónicas que pesaban sobre la usura, unos tipos de interés más bajos y su adopción por las instituciones públicas, en particular por la propia ciudad de Valencia, que lo convertirá en el principal instrumento de sus finanzas. En todo caso, esta innovación financiera que daba acceso al crédito a amplias capas de la población y a su vez hacía circular numerosos capitales que de otra manera hubieran quedado quizá amortizados en manos de viudas, huérfanos, nobles, clérigos o ciutadans, que permitía satisfacer necesidades de consumo y de inversión, no vino a subvertir, sino a reforzar, las bases estructurales del sistema feudal, al unirse los censales y violarios a los censos enfitéuticos y otros mecanismos de extracción de rentas de las clases productivas.

El libro de García Marsilla abordaba también lo que ha sido y continúa siendo una vigorosa y fecunda línea de investigación, la tercera que trataré en estas páginas, centrada en la formación y el desarrollo de una deuda pública consolidada, sustentada en la venta de censales y violarios, esto es, en el crédito a largo plazo. Contrariamente a las consideraciones negativas de la historiografía de los años setenta, que insistía en la asfixia de las finanzas locales por el peso aplastante del servicio de la deuda -pago de pensiones y amortización de capitales-, los estudios llevados a cabo a partir de mediados de los noventa han contribuido a matizar sensiblemente esta interpretación, al demostrar que no existían unas previas haciendas municipales que se vieron extenuadas por la carga financiera que representaba la deuda pública, sino que fue esta la que contribuyó de manera determinante a la creación de un verdadero sistema fiscal y financiero, al requerir el establecimiento de impuestos ordinarios y regulares con el que asegurar el pago de los intereses de la deuda. No es que la deuda crease el impuesto, porque este, tanto si era directo como indirecto, existía ya con anterioridad, pero se trataba en su mayor parte de exacciones extraordinarias, puntuales, con el fin de sufragar una necesidad concreta (el gasto de una campaña militar, las más de las veces, la construcción de una muralla y otras obras públicas, peticiones de subsidios por parte del monarca, etc.). Lo que hizo la deuda fue convertir el impuesto en un ingreso ordinario, regular, de las finanzas locales.

La atención se centró inicialmente en la deuda pública municipal, no solo porque esta ya venía siendo examinada para las grandes ciudades de la Corona de Aragón desde mediados de los años cincuenta (Roustit, 1954, para Barcelona; Santamaría, 1972-73, para Mallorca; y Belenguer, 1976, para Valencia), sino también como una derivación de los estudios sobre la fiscalidad y las finanzas locales que desde principios de los noventa se estaban llevando a cabo en Cataluña y el País Valenciano, en torno a Manuel Sánchez Martínez y Antoni Furió, respectivamente. De la colaboración entre ambos grupos, el catalán y el valenciano, surgirían dos iniciativas importantes, el coloquio sobre Corona, municipios y fiscalidad en la baja Edad Media, celebrado en Lleida el 1995 (Sánchez Martínez y Furió, 1996, con dos contribuciones dedicadas fundamentalmente a la deuda pública, la de García Marsilla y Sáiz sobre la ciudad de Valencia, 1996, y la de Urgell sobre Mallorca, 1996), y el número monográfico de la Revista d'história medieval de 1996 sobre la génesis de la fiscalidad municipal (Furió, 1996). Anteriormente a ambas publicaciones, ya algunos miembros de ambos equipos habían aportado estudios monográficos sobre el peso de la deuda pública en las haciendas municipales de algunas villas valencianas y catalanas, como Vicent Olaso (1987), Pau Viciano (1990 y 1992), Marc Torras (1996) y Antonio J. Mira Jódar (1997). En los años siguientes, yo mismo me ocuparía de ofrecer sucesivas síntesis sobre la deuda pública municipal en la Corona de Aragón y en Europa occidental, así como trabajos monográficos sobre la relación entre el impuesto y la deuda pública en la ciudad de Valencia (Furió, 1999, 
2002a, 2002b y 2005). Por su parte, Manuel Sánchez ofrecería igualmente una síntesis sobre la deuda pública en las ciudades de la Corona de Aragón, seguida de una importante contribución sobre el papel de la Corona en los orígenes del endeudamiento censal de los municipios catalanes (Sánchez Martínez, 2003 y 2006a), a la vez que se publicaban las tesis de Jordi Morelló (2001) y Pere Verdés (2004) sobre la deuda en Reus y Valls y en Cervera, respectivamente. Poco después Pere Verdés (2007) destacaba el papel de Barcelona como capital del mercado de la deuda pública catalana en la baja Edad Media y el grupo ofrecía una primera aproximación sintética a la deuda pública en la Cataluña bajomedieval, compendiando los trabajos hasta el momento y abriendo nuevas perspectivas de investigación hacia otras administraciones públicas, como la Diputación del General (Sánchez Martínez, 2009b). A los grupos valenciano y catalán no tardarían en unirse el mallorquín y el aragonés, ya en las primeras décadas del siglo XXI. El primero, nucleado en torno a Pau Cateura $(2005,2008,2014$ y 2015), ha contado con las aportaciones, entre otros, de Jaume Palou Santandreu (2000), Jordi Morelló (2002, 2007 y 2009), Guillem Morro (2006), Ricard Urgell (2009), Ricard Navarro Gómez (2009) y Antoni Mayol Llompart (2009), que han destacado en particular la dependencia de la deuda pública mallorquina de los inversores barceloneses, pero también su extensión a otras villas de la isla más allá de la capital del reino. En el caso de Aragón, tras una primera aproximación exploratoria de Juan Abella Samitier (2009) sobre la deuda en las villas del reino, Carlos Laliena y María Teresa Iranzo (2014 y 2016) y Mario Lafuente (2019) han estudiado la deuda pública en Zaragoza y otras ciudades y señoríos aragoneses.

En la Corona de Aragón, como en general en otros reinos y territorios durante la baja Edad Media, estudiar la deuda pública ha significado estudiar, sobre todo, la deuda de las haciendas municipales. En los últimos años se ha incrementado el número de monografías sobre su impacto en las finanzas de diversas ciudades (Ortí, 2009; Martí, 2010 y 2013; Reixach, 2018; García-Oliver, 2018), e incluso se han hecho intentos por cuantificar su volumen a escala regional, que han permitido cifrar, por ejemplo, la deuda municipal global del reino de Valencia a finales del siglo XV en cerca de tres millones de sueldos anuales (Furió, 2018; Viciano, 2018b). Pero en los últimos años la atención se ha ampliado también a la deuda pública emitida por el rey y por el reino, este último a través de las Diputaciones Generales de los tres territorios, Aragón, Cataluña y Valencia, conocidas en estos dos últimos casos como Generalitat (en realidad, la deuda pública de la Diputación General de Aragón fue estudiada ya a finales de los setenta por Sesma Muñoz, 1977; la de Valencia fue objeto de la tesis de Muñoz Pomer, 1987 y 2013; y la de Cataluña está siendo analizada en los trabajos más recientes de Sánchez Martínez, 2009, 2013 y 2019; véase también Martí Arau, 2018). Por mi parte, me he ocupado de la comparación entre el volumen y la incidencia de la deuda pública en las tres instancias de la administración pública -la municipal, la del reino y la del rey- y en los diferentes estados de la Corona de Aragón, primero de manera indiciaria y después de forma más analítica, cuantitativa y cualitativamente (Furió, 2015 y 2020; Furió y García Marsilla, 2018). Todos estos trabajos han permitido vincular estrechamente el desarrollo de la deuda pública con la construcción del Estado, tema justamente de un reciente congreso internacional con motivo de los 600 años de la Generalitat valenciana ( $\mathrm{La} \mathrm{Veu} \mathrm{del}$ Regne, 2018), y destacar el temprano nacimiento de la deuda pública estatal en la Corona de Aragón, en la segunda mitad del siglo XIV, antes de que lo hiciesen también los Países Bajos, Castilla y Francia, a finales del siglo XV y principios del XVI. También han mostrado la desviación de una parte sustancial de los ingresos fiscales en beneficio de los acreedores de la deuda pública, lo que contribuyó no solo a ampliar el consenso social en torno al impuesto, sino también a garantizar la estabilidad y continuidad del sistema hasta bien entrados los tiempos modernos.

En contraste con lo que hemos visto para la Corona de Aragón, los trabajos no son tan numerosos y variados para la deuda pública en Castilla, quizá porque su implantación -en forma de censos y jurosfue más tardía, tanto en las haciendas municipales como en las finanzas reales, ya durante el reinado de los Reyes Católicos, y en estrecha conexión también con una readaptación de la fiscalidad, en particular la “alcabala real”, aunque algunas tesis recientes sugieren una cronología más precoz (Pardos, 1984; Carrera, 1987; Asenjo, 2008; Carretero y Galán, 2013; Collantes de Terán, 2019; Gálvez, 2019). 
La cuarta y última gran línea de investigación que me propongo examinar aquí es la referida al crédito y el endeudamiento privados, tanto por parte de campesinos como de señores, eclesiásticos y burgueses. Dejando aparte el préstamo judío, al que ya me he referido en páginas anteriores, el crédito privado tenía una dimensión diferente -y a menudo también unos actores distintos- según se tratase de a corto plazo o a largo plazo. El primero, en forma sobre todo de obligaciones y compraventas a plazos o de pago diferido, de préstamos a interés o de comandas y depósitos, fue siempre muy importante, sobre todo al principio, en los siglos XIII y XIV, pero incluso después, cuando empezó a difundirse el segundo, en forma de censales y violarios, en la primera mitad del Trescientos, y a generalizarse, a partir del último cuarto de esta misma centuria, siguió ocupando un lugar muy destacado, especialmente, pero no solo, en el crédito rural y el endeudamiento campesino. Además de su dimensión financiera, tanto para cubrir las necesidades de consumo como para facilitar la inversión productiva -compra de tierras y casas, de animales de tiro, de ganado, de utillaje agrícola-, el crédito contribuía igualmente a paliar la escasez de la masa monetaria en circulación, ya que las deudas, reificadas, eran utilizadas como instrumentos de pago, de forma similar al papel moneda o billetes de épocas posteriores (Furió y García Marsilla, 2014). Dado, por otra parte, que pocas transacciones, formales o informales, se saldaban al contado, difiriendo el pago o financiándolo con instrumentos crediticios, el crédito no solo resulta omnipresente en la documentación medieval, sino que contribuía poderosamente a lubrificar y dinamizar la vida económica.

Quizá por ello, y al contrario que la deuda pública, cuya tardía implantación puede explicar la menor atención historiográfica que se le ha dispensado, el crédito privado, y en particular el crédito rural, ha suscitado mayor interés entre los historiadores castellanos, desde el artículo de Castán Lanaspa al que ya me he referido anteriormente y los sucesivos trabajos de Mercedes Borrero (1986, 2006 y 2013) y José Luis Villalonga (2007) sobre el campo sevillano y, en general, el mundo rural andaluz, incluyendo la gestión de la gran propiedad, a la tesis de Hilario Casado (1987) sobre la comarca de Burgos, las contribuciones de Tamara Somoza (2014), Octavio Colombo (2015 y 2016) y Reglero de la Fuente (2020) sobre el endeudamiento campesino y, sobre todo, la tesis de David Carvajal (2013) sobre el crédito privado en la Castilla de finales del siglo XV y principios del XVI. En realidad, la mayoría de los trabajos citados se centran en esta cronología, a caballo de la Edad Media y los Tiempos Modernos, en la que la documentación es más abundante. De igual modo, el crédito rural ha podido ser estudiado también para Navarra, aunque, en este caso, para un período anterior (Carrasco, 1987; Miranda, 2000).

Censales y violarios constituían un capítulo de ingresos tan sustancial o más que las rentas agrarias en las haciendas señoriales, como muestra el caso de Catarroja, en el reino de Valencia, estudiado por Pau Viciano, quien también ha analizado las estrategias inversoras en el mercado del crédito, tanto público como privado, de otros señoríos, incluidos los eclesiásticos, y del patriciado urbano (Viciano, 1989, 1991a, 1991b, 1993, 1995 y 2008). A su vez, el pago de las pensiones se imponía entre los gastos, revelando el alto grado de endeudamiento de muchos señoríos, sobre todo en el caso valenciano, que acabaron cambiando de manos, de un linaje aristocrático a otro, recomponiendo el mapa señorial y facilitando la formación de grandes estados nobiliarios, como ocurrió con el ducado de Gandía, en poder de los Borja, y de otros señoríos adquiridos por otro príncipe de la Iglesia, el cardenal Mendoza, aprovechando las dificultades financieras de sus antiguos titulares (Pastor Zapata, 1992, 1997 y 2000; Franco, 1982 y 1992; Pons, 1995; Furió, 1993 y 1997; GarciaOliver, 1997; López Rodríguez, 2005).

Por su parte, el crédito rural y el endeudamiento campesino han sido ampliamente estudiados en Cataluña, Mallorca y el País Valenciano, aunque desde fuentes y perspectivas muy diferentes, principalmente protocolos notariales y registros judiciales. En general, todos los trabajos muestran el alto grado de endeudamiento de las comunidades campesinas y su incidencia sobre la desigualdad económica y social (Furió, 1993 y 1998; Padrós, 1997; Aleixandre, 2006; Muntaner Alsina, 2013; Soldevila, 2014). Sin embargo, importaba mucho de qué tipo de crédito se trataba, si a corto o a largo plazo, ante quién se había declarado y formalizado, qué seguridades, incluyendo la hipoteca inmobiliaria, lo garantizaban y qué 
motivaciones llevaban al prestador y al tomador, respectivamente, a concederlo y obtenerlo. El crédito de mayor volumen económico y duración temporal, tanto a corto plazo -préstamos a interés, depósitos, comandas, reconocimientos de deuda-, como a largo - censales y violarios, con una gran cantidad de fórmulas jurídicas y cláusulas de seguridad para el acreedor, en caso de impago por parte del deudor- solía ser registrado por un notario, en presencia de testigos (Furió, 2005), mientras que el pequeño crédito, en forma de obligaciones, es decir, promesas o compromisos de pago por compras a plazo o pagos diferidos, podía ser registrado, de forma gratuita, en las cortes judiciales (del justícia en Valencia y del veguer o el batlle en Cataluña y Mallorca) (Furió, 2006; Mayol, 2015). Este pequeño crédito a corto plazo, como ha demostrado Pau Viciano para las villas valencianas de Castellón y Cocentaina en el siglo XV, no buscaba solo satisfacer necesidades perentorias de consumo, sino que era utilizado también para financiar inversiones productivas de las familias campesinas y de las capas más modestas de la población (Viciano, 2013 y 2018).

En la concesión de créditos a los campesinos, sin embargo, las motivaciones y estrategias de los prestadores no parecen haber sido las mismas en toda la Corona de Aragón. Gabriel Jover y Antoni Mas sugieren que el endeudamiento fue un instrumento para la desposesión campesina, esto es, para la apropiación de sus tierras por parte de señores y propietarios urbanos, que pudieron crear con ellas grandes explotaciones, llamadas possessions, similares a los poder italianos (Jover, 1995 y 1997; Mas, 2008). De hecho, recuerda bastante la estrategia de conquista territorial practicada por la burguesía ciudadana del centro y norte de Italia que invertía en el crédito rural. ${ }^{9}$ No ocurría lo mismo en el reino de Valencia, en donde el mercado del crédito era principalmente un mercado campesino -como lo era también el de la tierra-, e incluso cuando los acreedores eran señores y burgueses, principalmente en el crédito a largo plazo en forma de censales y violarios -pero incluso aquí, en este tipo de crédito, los campesinos también eran mayoritarios, tanto entre los deudores como entre los acreedores-, pocas veces la morosidad y la insolvencia terminaban con la confiscación de las tierras del deudor y su venta en subasta judicial. Y cuando esto ocurría raramente los acreedores se quedaban con las parcelas subastadas. Su objetivo no era acumular tierra, sino asegurarse la percepción regular de rentas. Para el campesino, recurrir al crédito, en particular el de largo plazo, asegurado con las propiedades del deudor, le proporcionaba los medios financieros para hacer pagos importantes o incluso comprar tierras. El precio que había de pagar por ello, sin embargo, era quedar atrapado en un endeudamiento estructural y añadir el pago regular de pensiones o intereses a las exacciones señoriales, el diezmo eclesiástico y los impuestos reales y municipales. El endeudamiento rural estaba profundamente enraizado en la fragilidad de las economías campesinas y su precario equilibrio para asegurar su reproducción, amenazada por las malas cosechas, el incremento de la fiscalidad y el pequeño tamaño de sus explotaciones. Señores y propietarios urbanos, no obstante, no aprovecharon el endeudamiento campesino para apoderarse de las tierras de sus deudores e introducir cambios profundos en el sistema de gestión, como ocurría en Italia y Mallorca. Lo que querían era más rentas, no más tierras, por lo que el crédito rural que proveían no pretendía subvertir las estructuras rentistas del sistema feudal, sino asegurar su estabilidad y continuidad (Furió et al., 1993; Furió, en prensa).

Las evoluciones recientes en los estudios sobre el crédito y los mercados financieros, especialmente en el mundo rural, que hemos reseguido en las páginas anteriores, desde los primeros trabajos sobre la usura y el préstamo a interés, fundamentalmente judío, en la primera mitad del siglo XX, hasta las líneas de investigación más recientes, que se ramifican en diversas direcciones, desde el marco teórico, doctrinal y legal del mercado del crédito y el estudio de los diferentes instrumentos financieros -préstamo a interés, crédito comercial y bancario, crédito a largo plazo en forma de censales y censos consignativos- a la deuda pública y el crédito privado, especialmente el crédito rural, muestran el vigor y la fecundidad de un tema de estudio sustancial, nuclear, que apela a múltiples áreas de conocimiento, desde la historia rural y agraria a la historia urbana, fiscal y financiera. También muestra la vitalidad de una historia económica que sigue siendo más histórica que econométrica, con datos y métodos cuantitativos, pero sin necesidad de imponer lógicas contemporáneas, neoclásicas o neoliberales, a las economías del pasado. 


\section{Bibliografía}

Abella Samitier, J. (2009). La deuda pública de los municipios aragoneses en los siglos XIV y XV. Anuario de Estudios Medievales, 39, 47-64.

Ackerley, M. I. (1994). Censos, censals i masies del monestir de la Portella: De la ruïna del segle XV a la recuperació del XVI-XVIII. Afers, 9, 575-597.

Aleixandre, T. (2004). El Liber Iudeorum núm. 90 de l'Aleixar (1344-1348): estudi i edició. Barcelona: Fundació Noguera.

Aleixandre, T. (2006). Endeudamiento, penyores y nivel de riqueza del campesinado catalán bajomedieval. In J. Bolós, A. Jarne y E. Vicedo (Eds.), Condicions de vida al món rural: Cinquè Congrés sobre Sistemes Agraris, Organització Social i Poder Local (pp. 79-94). Lleida: Institut d'Estudis Ilerdencs.

Aleixandre, T. (2009). El crédito rural judío en el Camp de Tarragona antes de la peste negra. In F. Sabaté \& C. Denjean (Eds.), Cristianos y judios en contacto en la Edad Media:polémica, conversión, dinero y convivencia (pp. 289-312). Lleida: Milenio

Aleixandre, T. (2015). Crédito y endeudamiento rural: la circulación del capital judio en la Girona del siglo XIV (1348-1391). Universidad de Valencia, tesis doctoral inédita.

Alloza, Á., Fernández, F., y García Guerra, E. (2012). Comercio, banca y sociedad en los reinos hispánicos, siglos XIV-XVIII. Madrid: Polifemo.

Alibart, M.-J. (1969). Les rentes à vie et les rentiers de la ville de Saint-Omer au XVe siècle. Bulletin trimestriel de la Société Académique des Antiquaires de la Morinie, 21, 240-250.

Altisent, A. (1967). El monasterio de Poblet y unos judíos prestamistas de la Segarra (s. XIV-XV). Sefarad, 27, 282-289.

Andreau, J., Béaur, G., y Grenier, J.-Y. (Dir.) (2006). La dette publique dans l'histoire. París: Comité pour l'histoire économique et financière de la France.

Andrés Robres, F. (1987). Crédito y propiedad de la tierra en el País Valenciano (1600-1810). Valencia: Edicions Alfons el Magnànim.

Arquero Caballero, G. F. (2014-15). 'Si dio a usura pública o secretamente': aproximación a la usura en los manuales de confesores de la Castilla bajomedieval. Baetica, 36/37, 157-179.

Asenjo, M. (2008). Ciudades y deuda pública en Castilla. La adaptación fiscal del impuesto de la 'alcabala real' a las nuevas exigencias de la sociedad política (1450-1520). In S. Cavaciocchi (Ed.), La fiscalità nell'economia europea secc. XIII-XVIII (Trentanovesima Settimana di Studi, Prato 2007) (pp. 531-544). Florencia: Firenze University Press.

Astarita, C. (1992). Desarrollo desigual en los orígenes del capitalismo: el intercambio asimétrico en la primera transición del feudalismo al capitalismo. Mercado feudal y mercado protocapitalista, Castilla siglos XIII a XVI. Buenos Aires: Tesis 11 Grupo Editor.

Aurell, J. (1996). Els mercaders catalans al Quatre-cents: mutació de valors i procés d'aristocratització a Barcelona, 1370-1470. Lleida: Pagès.

Aurell, J. (2004). Los efectos del giro lingüístico en la historiografía reciente. RILCE. Revista de filología hispánica, 20, 1-16.

Aurell, J. (2005). La escritura de la memoria. De los positivismos a los postmodernismos. Valencia: PUV.

Baum, H.P. (1985). Annuities in late medieval Hanse towns. Business History Review, 59, 24-48.

Becker, M. B. (1956). Gualtieri di Brienne e la regolamentazione dell'usura a Firenze. Archivio Storico Italiano, 114, 734-740.

Belenguer Cebrià, E. (1976). València en la crisi del segle XV. Barcelona: Edicions 62.

Benito Ruano, E. (1970). Usuras y 'cambios' en el León medieval. Archivos leoneses, 24, 203-208.

Bennassar, B. (1960). En Vieille-Castille: ventes de rentes perpétuelles, première moitié du XVIe siècle. Annales, 15, 1.115-1.126. 
Bennassar, B. (1967). Valladolid au Siècle d'Or. Une ville de Castille et sa campagne au XVIe siècle. París: Mouton et cie.

Bergier, J.-F. (1962). Taux de l'intérêt et crédit à court terme à Genève dans la seconde moitié du XVI siècle. Studi in onore di Amintore Fanfani, Milán: A. Giuffrè editore, 89-119.

Bernal, A. M. (Ed.) (2000). Dinero, moneda y crédito en la monarquía bispánica. Madrid: Fundación ICOMarcial Pons.

Boldizzoni, F. (2013). La pobreza de Clio. Crisis y renovación en el estudio de la historia. Barcelona: Crítica.

Borrero, M. (1986). Efectos del cambio económico en el ámbito rural: los sistemas de crédito en el campo sevillano (fines del siglo XV y principios del XVI). In M. Á. Ladero Quesada (Ed.), En la España Medieval V. Estudios en Memoria del Profesor D. Claudio Sánchez Albornoz (pp. 219-244). Madrid.

Borrero, M. (2004). El papel de la tierra en el mercado del crédito rural. Andalucía, siglos XV y XVI. In S. Cavaciocchi (Ed.), Il mercato della terra, sec. XIII-XVIII (XXXV Settimana di Studi de l'Istituto Datini, Prato 2003) (pp. 901-914). Florencia: Le Monnier.

Borrero, M. (2006). Crédito y mundo rural en Andalucía. Préstamos y endeudamientos en tiempos de los Reyes Católicos. In M. García Fernández y C. A. González Sánchez (Eds.), Andalucía y Granada en tiempos de los Reyes Católicos (vol. I, pp. 25-40). Sevilla: Universidad de Sevilla-Universidad de Granada.

Borrero, M. (2013). Andalucía ante las crisis agrarias. La incidencia decisiva del factor endeudamiento a fines de la Edad Media. In Pere Benito Monclús (Ed.), Crisis alimentarias en la Edad Media. Modelos, explicaciones y representaciones (pp. 231-250). Lleida: Milenio.

Boyer, G. (1948). Le crédit à Toulouse avant le XIIIe siècle. Bulletin de l'Université et de l'Académie de Toulouse, 247-248.

Braudel, F. (1982). La Méditerranée et le monde méditerranéen à l'époque de Philippe II. París: Armand Colin.

Burke, P. (2010). ¿Qué es la historia cultural? Barcelona: Paidós.

Cantera Burgos, F. (1931). La usura judía en Castilla. Ciencia tomista, 43, 5-26.

Cantera Montenegro, E. (1982). Pleitos de usura en la diócesis de Osma en el último tercio del siglo XV. Anuario de Estudios Medievales, 12, 597-622.

Cantera Montenegro, E. (1999). Una familia de prestamistas y arrendatarios judíos en tiempos de la expulsión: Los Soto de Aranda de Duero. Espacio, Tiempo y Forma 3, 12, 11-46.

Capitani, O. (1958). Sulla questione dell'usura nel Medio Evo: a proposito del volume di John T. Noonan, The Scholastic Analysis of Usury, Harvard University Press, Cambridge Mass., 1957. Bullettino dell'Istituto storico italiano per il Medioevo, 70, 540-566.

Capitani, O. (1965). Il De peccato usure di Remigio de' Girolami. Studi Medievali, 6-2, 537-662.

Carande, R. y Lapeyre, H. (1959). Relaciones comerciales en el Mediterráneo durante el siglo XVI. VI Congreso de Historia de la Corona de Aragón (pp. 697-800). Madrid: Dirección General de Relaciones Culturales, Ministerio de Asuntos Exteriores.

Carrasco Pérez, J. (1980). Prestamistas judíos de Tudela a fines del siglo XIV (1382-1383). Miscelánea de estudios árabes y hebraicos, 29/2, 87-141.

Carrasco Pérez, J. (1982). Acerca del préstamo judío en Tudela a fines del siglo XIV según el registro del sello de 1383. Principe de Viana, 43, 909-948.

Carrasco Pérez, J. (1986a). El crédito judío en las villas navarras del Camino de Santiago (1339-1408). In Ninth International Economic History Congress Bern 1986. 9: Local and international credit in the Middle Ages and the 16th century (pp. 8-14). Zúrich: Verlag der Fachvereine.

Carrasco Pérez, J., (1986b). La actividad crediticia de los judíos en Pamplona (1349-1387). In Minorités et marginaux en France méridionale et dans la péninsule ibérique (VIIe-XVIIIe siècles). (Actes du Colloque de Pau, 27-29 mai 1984) (pp. 221-263). París : Éd. du CNRS. 
Carrasco Pérez, J. (1987). Crédito agrícola y deuda mudéjar en el reino de Navarra (1436-1441). Notas para su estudio. In Homenaje al profesor Darío Cabanelas Rodríguez (t. 1, pp. 203-215). Granada: Universidad de Granada.

Carrasco Pérez, J. (2002). Crédito judío y mercado del dinero en la villa de Laguardia y sus aldeas (1375-1415). In E. García Fernández (Ed.), Espacio, sociedad y economía. Actas de las Primeras Jornadas de Estudios Históricos de la Rioja Alavesa (Laguardia, 2001) (pp. 159-172). Vitoria-Gasteiz: Diputación Foral de Álava.

Carrasco Pérez, J. (2005). Crédito y usura en el ordenamiento legal y en la administración pública del reino de Navarra (siglos XII-XIV). In G. Todeschini, D. Quaglioni, y G. M. Varanini (Eds.), Credito e usura fra teologia, diritto e amministrazione. Linguaggi a confronto (sec. XII-XVI) (pp. 159-179). Roma: École française de Rome.

Carrasco Pérez, J. (2008). Fiscalidad, moneda y crédito en las juderías navarras del Camino de Santiago: Monreal (1266-1406). In J. Á. Sesma y C. Laliena (Eds.), La pervivencia del concepto. Nuevas reflexiones sobre la ordenación social del espacio en la Edad Media (pp. 299-379). Zaragoza: Universidad de Zaragoza.

Carrasco Pérez, J. (2009). El crédito judío en el reino de Navarra, según los padrones de deuda hebreos (1323-1328). In D. Pelaz, M. I. del Val Valdivieso, y P. Martínez Sopena, Castilla y el mundo feudal: homenaje al profesor Julio Valdeón (t. 2, pp. 237-250). Valladolid: Junta de Castilla y León-Universidad de Valladolid.

Carrasco Pérez, J. (2015). Crédito judío, deuda y morosidad en Navarra: cartas tornadas o quenaces (1329-1349). In R. Córdoba de la Llave, J. L. del Pino y M. Cabrera (Eds.), Estudios en homenaje al profesor Emilio Cabrera (pp. 93-110). Córdoba: Universidad de Córdoba.

Carrasco Pérez, J. (2019). Dinero y deuda: crédito judio en las villas navarras del Camino de Santiago, 1266-1413. Pamplona: Liber Ediciones.

Carrera Raya, F. J. (1987). Notas sobre algunos antecedentes iushistóricos de la deuda pública española: de los juros a los vales reales. Cuadernos informativos de derecho histórico público, procesal y de la navegación, 4/5, 603-634.

Carrère, C. (1967). Barcelone, centre économique à l'époque des difficultés, 1380-1462. París: Mouton et cie., 2 vols. Existe traducción catalana (1977), a cargo de Hermínia Grau, Barcelona, 1380-1462. Un centre económic en època de crisi. Barcelona: Curial.

Carrete Parrondo, C. y Moreno Koch, Y. (1995). Cristianos prestamistas a judíos en la aljama de Ávila (siglo XV). La ciudad de Dios, 208, 421-430.

Carretero Zamora, J. M. y Galán Sánchez, A. (2013). Las políticas del gasto: el servicio del reino, el crédito y la deuda en Castilla, de los Reyes Católicos a Carlos V. In Á. Galán y J. M. Carretero (Eds.), El alimento del Estado y la salud de la Res Publica: Origenes, estructura y desarrollo del gasto público en Europa (pp. 473-500). Madrid: Instituto de Estudios Fiscales.

Carvajal, D. (2013). Crédito privado y deuda en Castilla (1480-1521). Valladolid, tesis doctoral inédita.

Casado, H. (1987). Señores, mercaderes y campesinos. La comarca de Burgos a fines de la Edad Media. Valladolid: Junta de Castilla y León.

Castán Lanaspa, G. (1983). Créditos, deudas y pagos en el área rural castellano-leonesa (siglos XI-XIV). Studia historica. Historia medieval, 1, 67-86.

Castillo Pintado, A. (1963). Los juros de Castilla. Apogeo y fin de un instrumento de crédito. Hispania. Revista española de historia, 23, 43-70.

Castillo Pintado, A. (1970). El mercado del dinero en Castilla a finales del siglo XVI. Anuario de historia económica y social, 3, 91-104.

Cateura, P. (2005). La guerra de Cerdeña y las finanzas municipales: la deuda pública de Mallorca (1355). In R. Narbona (Ed.), La Mediterrània de la Corona d'Aragó, segles XIII-XVI \& VII Centenari de la Sentència Arbitral de Torrellas, 1304-2004: XVIII Congrés d'História de la Corona d'Aragó, València 2004 (pp. 209-224). Valencia: Universidad de Valencia. 
Cateura, P. (2008). El rey burlado: deuda pública y fiscalidad en el reino de Mallorca (siglo XV). Anuario de Estudios Medievales, 38, 185-211.

Cateura, P. (2014). Los compradores de deuda pública en el reino de Mallorca (1355-1429). In M. Borrero, J. Carrasco, y R. Peinado (Eds.), Agentes de los sistemas fiscales en Andalucia y los reinos hispánicos (siglos XIIIXVII): un modelo comparativo, IV Col. Arca Comunis (pp. 31-42). Madrid: Instituto de Estudios Fiscales.

Cateura, P. (2015). Els inversors en deute públic al regne de Mallorca (segles XIV-inicis del segle XV): anàlisi prosopogràfic. In P. Cateura, J. Maíz, y Ll. Tudela (Eds.), Inversors, banquers i jueus. Les xarxes financeres a la Corona d'Aragó (s. XIV-XV) (pp. 15-38). Palma: Edicions Documenta Balear.

Cervantes Peris, F. J. (1993). La Receptoría General del antiguo patrimonio de María de Luna. La gestión de la deuda censal en unos estados feudales del XV valenciano. Pedralbes, 13/2, 249-254.

Cervantes Peris, F. J. (1996). El antiguo patrimonio de María de Luna: crédito censal y consolidación feudal (1372-1425). In XV Congreso de Historia de la Corona de Aragón, 1: El poder real en la Corona de Aragón, siglos XIV-XVI (pp. 51-68). Zaragoza: Gobierno de Aragón.

Clavero, B. (1977). Prohibición de la usura y constitución de rentas. Moneda y crédito. Revista de economía, $143,107-131$.

Clavero, B. (1985). Usura. del uso económico de la religión en la historia. Madrid: Tecnos.

Clavero, B. (1991). Antidora. Antropología católica de la economía moderna. Milán: Giuffrè. Traducción francesa (1996) publicada bajo el título La Grâce du Don. París: Albin Michel.

Collantes de Terán, A. (2019). Albaquías, alcances y deudas en la gestión de la hacienda concejil sevillana a fines de la Edad Media. In F. Garnier y A. Jamme (Eds.), Cultures fiscales en Occident du Xe au XVIIe siècle: études offertes à Denis Menjot (pp. 131-142). Toulouse: Presses Universitaires du Midi.

Colombo, O. (2003-06). La negociación en torno a la usura en Castilla, 1258-1405. Economía, poder y religión en la Baja Edad Media. Anales de la Universidad de Alicante. Historia medieval, 14, 85-110.

Colombo, O. (2015). ¿Por qué el campesino se endeuda? El significado de la usura medieval (Castilla, s. XV). Sociedades Precapitalistas. Revista de Historia Social, 5/1.

Colombo, O. (2016). Los dueños del dinero. Prestamistas abulenses a mediados del siglo XV. Espacio, Tiempo y Forma 3, 29, 249-277.

Conde Delgado de Molina, R. (1997). Crédito, deuda y banca: las técnicas financieras en la segunda mitad del cuatrocientos. In E. Sarasa y E. Serrano (Eds.), La Corona de Aragón y el Mediterráneo. Siglos XV-XVI (pp. 73-86). Zaragoza: Institución Fernando el Católico.

Coniglio, G. (1952). L'usura a Lucca ed una Bolla di Niccolò V del 1452. Rivista di storia della chiesa in Italia, 6, 259-264.

Coryn, H. A. (1945). L'abbaye, centre de crédit médiéval. Revue de la banque, 9, 265-275.

Costa, M. J. B. de A. (1961). Raizes do censo consignativo: para a história do crédito medieval português. Coimbra: Atlântida.

Crespo Álvarez, M. (2002). Judíos, préstamos y usuras en la Castilla medieval. De Alfonso X a Enrique III. Edad Media. Revista de historia, 5, 179-216.

De Antonio Rubio, M. G. (2004). La judería de Ribadavia y la actividad pecuniaria y prestataria de algunos judíos gallegos en la Baja Edad Media. In A. Villar(Ed.), Elpatrimonio hebreo en la España medieval: singladuras del Arca (pp. 217-238). Córdoba: Universidad de Córdoba.

De Antonio Rubio, M. G. (2006). Un contrato de préstamo entre judíos de Ourense y Portugal. In M. González Jiménez e I. Montes (Eds.), La Peninsula Ibérica entre el Mediterráneo y el Atlántico, siglos XIII-XV (pp. 225-232). Cádiz: Sociedad Española de Estudios Medievales.

De Antonio Rubio, M. G. (2016). Préstamos con interés encubierto de cristianos y judíos en la Galicia del siglo XV. Sefarad, 76, 491-508.

De la Roncière, Ch. M. (1973). Un changeur florentin du Trecento: Lippo di Fede del Sega (1285 env.1363 env.). París: SEVPEN. 
De Malafosse, J. (1951). Contribution à l'étude du crédit dans le Midi aux Xe et XIe siècles: les suretés réelles. Annales du Midi, 63, 105-148.

Denjean, C. (1998). Le crédit juif dans les campagnes cerdanes de 1260 à 1493. In M. Berthe (Ed.), Endettement paysan et crédit rural dans l'Europe médiévale et moderne. Actes des XVIIes Journées Internationales de l'Abbaye de Flaran (1995) (pp. 185-197). Toulouse: Presses Universitaires du Mirail.

Denjean, C. (2006). Crèdit jueu i usures cristianes a les viles rurals catalanes a la fi del segle XIII: el jueu Issach Biona, el corredor Guillem Franchea i els canvistes de Barcelona: un mercat d'usures i barates a Vilafranca del Penedès a la fi del segle XIII. Revista de dret históric català, 6, 259-283.

Denjean, C. (2009). Les sources de l'histoire du crédit juif en Catalogne. In F. Sabaté y C. Denjean (Eds.), Cristianos y judios en contacto en la Edad Media: polémica, conversión, dinero y convivencia (pp. 291-311). Lleida: Milenio.

Denjean, C. (2010). Réseaux relationnels des prêteurs juifs de Cerdagne et de Roussillon, 1260-1420. In D. Coulon, Ch. Picard, y D. Valérian (Eds.), Espaces et réseaux en Méditerranée, VIe-XVIe siècle. 2: La formation des réseaux (pp. 255-274). París: Éditions Bouchène.

Denjean, C. (2011). La loi du lucre: l'usure en procès dans la Couronne d'Aragon à la fin du Moyen Âge, Madrid: Casa de Velázquez.

Denjean, C. (2017). Crédit et usure. Juifs et chrétiens face à l'incertitude sur les marchés en Catalogne à la fin du Moyen Âge. In G. Castelnuovo y S. Victor (Eds.), L'bistoire à la source: acter, compter, enregistrer (Catalogne, Savoie, Italie, XIIe-XVe siècle): mélanges offerts à Christian Guilleré (pp. 267-282). Chambéry: Université de Savoie.

De Roover, R. (1942). Money, banking and credit in medieval Bruges. The Journal of Economic History, 2, 52-65.

De Roover, R. (1964). Les doctrines économiques des scolastiques: à propos du traité sur l'usure d'Alexandre Lombard. Revue d'histoire ecclésiastique, 59, 854-866.

Des Marez, G. (1898). Étude sur la propriété foncière des villes au Moyen Âge et spécialement en Flandre. Gante: Engelcke.

Dhondt, J. (1941). Notes d'histoire du crédit. Revue de la banque, 5, 237-244.

Doucet, R. (1934). Finances municipales et crédit public à Lyon au XVIe siècle. Revue d'histoire économique et sociale, 22, 19-66, 283-360.

Dubled, H. (1955). Aspects de la vie économique de Strasbourg aux XIIIe et XIVe siècle: Baux et rentes. Introduction à l'histoire économique des institutions religieuses. Archives de l'Église d'Alsace, 6, 23-56.

Dufourcq, Ch.-E. y Gautier-Dalché, J. (1983). Historia económica y social de la España cristiana en la Edad Media. Barcelona: El Albir.

Epstein, S. R. (2009). Libertad y crecimiento. El desarrollo de los estados y de los mercados en Europa, 1300-1750. Valencia: PUV.

Feliu Montfort, G. (2007). Mercaders-banquers barcelonins: l'endeutament de la monarquia i la fallida de la taula de canvi de Pere des Caus i Andreu d'Olivella el 1381. Barcelona. Quaderns d'história, 13, 197-210.

Feliu Montfort, G. (2016). Els primers llibres de la Taula de Canvi de Barcelona. Barcelona.

Fernàndez Cuadrench, J. (1998). Crédit juif et solidarité villageoise dans les campagnes barcelonaises au XIIIe siècle. M. Berthe (Ed.), Endettement paysan et crédit rural dans l'Europe médiévale et moderne. Actes des XVIIes Journées Internationales de l'Abbaye de Flaran (1995) (pp. 169-183). Toulouse: Presses Universitaires du Mirail.

Fournial, E. (1963). L'indexation des créances et des rentes au XIVe siècle. Le Moyen Âge, 69, 583-596.

Franco Silva, A. (1982). La herencia patrimonial del gran cardenal de España D. Pedro González de Mendoza. Historia. Instituciones. Documentos, 9, 453-491.

Franco Silva, A. (1992). Las baronías valencianas del Gran Cardenal de España, D. Pedro González de Mendoza. In Lluis de Santángel i el seu temps (pp. 217-227). Valencia: Ajuntament de València. 
Furió, A. (1993). Diners i crèdit: els jueus d'Alzira en la segona meitat del segle XIV. Revista d'história medieval, 4, 127-160.

Furió, A. (1993). Crédito y endeudamiento: el censal en la sociedad rural valenciana (siglos XIV-XV). In E. Sarasa y E. Serrano (Eds.), Señorío y feudalismo en la Peninsula Ibérica: Ss. XII-XIX (t. 1, pp. 501-534). Zaragoza: Institución Fernando el Católico.

Furió, A. (Ed.) (1996). La gènesi de la fiscalitat municipal (segles XII-XIV), núm. 7 de la Revista d'história medieval.

Furió, A. (1997). Senyors i senyories al País Valencià al final de l'Edat Mitjana. Revista d'História Medieval, 8, 109-151.

Furió, A. (1998). Endettement paysan et crédit dans la Péninsule Ibérique au Bas Moyen Âge. In M. (Ed.), Endettement paysan et crédit rural dans l'Europe médiévale et moderne. Actes des XVIIes Journées Internationales de l'Abbaye de Flaran (1995) (pp. 139-167). Toulouse: Presses Universitaires du Mirail.

Furió, A. (1999). Deuda pública e intereses privados. Finanzas y fiscalidad municipales en la Corona de Aragón. Edad Media. Revista de historia, 2, 35-80.

Furió, A. (2002a). Les dépenses de la métropole valencienne (XIVe-XVe siècles). In D. Menjot y M. Sánchez Martínez (Eds.), La fiscalité des villes au Moyen Âge (Occident méditerranéen). 3: La redistribution de l'impôt (pp. 193-202). Toulouse: Privat.

Furió, A. (2002b). La dette dans les dépenses municipales. In D. Menjot y M. Sánchez Martínez (Eds.), La fiscalité des villes au Moyen Âge (Occident méditerranéen). 3: La redistribution de l'impôt (pp. 321-350). Toulouse: Privat.

Furió, A. (2004). El mercado de la tierra en la Valencia de los siglos XIII-XV. Crédito, endeudamiento y compraventa de parcelas. In S. Cavaciocchi (Ed.), Il mercato della terra, sec. XIII-XVIII (XXXV Settimana di Studi de l'Istituto Datini, Prato 2003) (pp. 797-812). Florencia: Le Monnier.

Furió, A. (2005a). Impôt et dette publique. Système fiscal et stratégies financières à Valence à la fin du Moyen Âge. In D. Menjot, A. Rigaudière y M. Sánchez Martínez (Eds.), L'Impôt dans les villes de l'Occident méditerranéen (pp. 39-62). París: Comité pour l'histoire économique et financière de la France.

Furió, A. (2005b). Le crédit dans les registres notariaux de la région de Valence au bas Moyen Âge. Mélanges de l'École française de Rome. Moyen Âge, 117, 407-440.

Furió, A. (2006). Crédit, endettement et justice: préteurs et débiteurs devant le juge dans le royaume de Valence (XIIIe-XVe siècle). In J. Mayade-Claustre (Ed.), La dette et le juge. Juridiction gracieuse et juridiction contentieuse du XIIIe au XVe siècle (pp. 19-54). París: Éditions de la Sorbonne.

Furió, A. (2015). Estados, mercados y crecimiento económico (S. R. Epstein en el recuerdo). In Estados y mercados financieros en el Occidente cristiano (siglos XIII-XVI). XLI Semana de Estudios Medievales (Estella, 2014) (pp. 55-81). Pamplona: Gobierno de Navarra.

Furió, A. (2018). El deute públic municipal al Regne de València en la Baixa Edat Mitjana: un assaig de quantificació. In D. Igual y G. Navarro (Eds.), El Pais Valenciano en la Baja Edad Media. Estudios dedicados al profesor Paulino Iradiel (pp. 71-136). Valencia: PUV.

Furió, A. (2019). Los efectos del endeudamiento público en los países de la Corona de Aragón. In A. Jamme y P. Verdés (Eds.), Los origenes de la deuda publica en Europa (siglos XIII-XVII) (actas en prensa).

Furió, A. (2020). Deuda municipal, deuda del reino y deuda del rey. Los diferentes niveles de la deuda pública en la Corona de Aragón: el caso del reino de Valencia. In A. Jamme y P. Verdés (Eds.), Los orígenes de la deuda publica en Europa (siglos XIII-XVII) (actas en prensa).

Furió, A. (en prensa). Rents Instead of Land. Credit and Peasant Indebtedness in late medieval Mediterranean Iberia: the kingdom of Valencia. Continuity and Change.

Furió, A., García Marsilla, J. V., Mira Jódar, A. J., Vercher, S., y Viciano, P. (1993). Endeutament imorositat en una comunitatrural. El censal a Sueca a finals del segle XV. In Actes de la V Assemblea d'História de la Ribera (Almussafes 1988) (pp. 119-165). Almussafes: Ajuntament d'Almussafes. 
Furió, A. y García Marsilla, J. V. (2014). Espèces et créances en circulation: monnaie métallique et crédit comme monnaie dans le royaume de Valence vers 1300. In M. Bourin, F. Menant y Ll. To Figueras (Eds.), Dynamiques du monde rural dans la conjoncture de 1300: échanges, prélèvements et consommation en Méditerranée occidentale (pp. 493-532). Roma: École française de Rome.

Furió, A. y García Marsilla, J. V. (2018). La deuda pública en la Corona de Aragón: instancias de poder (municipal, real y del reino), cronología y magnitudes. In A. Jamme y P. Verdés (Eds.), Los orígenes de la deuda publica en Europa (siglos XIII-XVII) (actas en prensa).

Fryde, E. B. (1949 y 1950). Materials for the study of Edward III's credit operations, 1327-1348. Bulletin of the Institute of Historical Research, 22, 105-138, y 23, 1-30.

Fryde, M. F. (1964). Studies in the history of public credit of German principalities and towns in the Middle Ages. Studies in Medieval and Renaissance history, 1, 223-292.

Gálvez Gambero, F. (2019). Endeudamiento y financiación de la Corona de Castilla en época Trastámara (ca. 1387-1504). Universidad de Málaga, tesis doctoral inédita.

García, A. (1982). El préstamo judío en la Huerta de Valencia durante el siglo XIV. Annals de l'IDECO, $1,181-223$.

García Cárcel, R. (1975). Las Germanias de Valencia. Barcelona: Península.

García Cárcel, R. (1976). Los censales y su repercusión en las Gerrnanias. I Congreso de Historia del País Valenciano (t. III, pp. 133-142). Valencia: Universidad de Valencia.

García Cárcel, R. (1 de marzo de 1988). Los banqueros de Carande. El País.

García de Valdeavellano, L. (1973). El 'renovo'. Notas y documentos sobre los préstamos usurarios en el reino astur-leonés (siglos X-XI). Cuadernos de Historia de España, LVII-LVIII, 408-448.

García Marsilla, J. V. (1995). Crédito y banca en el Mediterráneo medieval: la quiebra del cambista valenciano Francesc de Pals. Anuario de Estudios Medievales, 25, 127-150.

García Marsilla, J. V. (2002). Vivir a crédito en la Valencia medieval: de los origenes del sistema censal al endeudamiento del municipio. Valencia: PUV.

Garcia-Oliver, F. (2018). Memòria fiscal i escalada del deute en una vila valenciana medieval: Gandia a través dels seus comptes. In D. Igual y G. Navarro (Eds.), El País Valenciano en la Baja Edad Media. Estudios dedicados al profesor Paulino Iradiel (pp. 211-232). Valencia: PUV.

Garcia-Oliver, F. (1997). El censal en el senyoriu: Valldigna (1393-1530). Revista d'historia medieval, 8, 153-173.

García Sanz, A. (1955-57). Precedentes de la letra de cambio en la Curia Fumada. Ausa, 2, 533-540.

García Sanz, A. (1957). La Banca en los siglos XIII y XIV según el Aureum Opus. Boletín de la Sociedad Castellonense de Cultura, 33, 201-205.

García Sanz, A. (1958-60). Un contrato de 'commenda' de 1221. Ausa, 3,166-172.

García Sanz, A. (1958-60). Tipos ausetanos de la 'commenda' en el siglo XIII. Ausa, 3, 284-293.

García Sanz, A. (1961-63). Los intereses en los préstamos de los judíos de Vich durante la primera mitad del siglo XIV. Ausa, 4, 247-251.

García Sanz, A. (1961). El censal. Boletín de la Sociedad Castellonense de Cultura, 37, 281-310.

García Sanz, A. (1988). El violari. In Homenatge al Dr. Sebastià García Martínez (t. I, pp. 179-188). Valencia: Universitat de València.

Génestal, R. (1901). Rôle des monastères comme établissements de crédit: étudié en Normandie du XIe à la fin du XIIIe siècle. París: Arthur Rousseau, éditeur.

Gessler, J. (1928). Études d'histoire financière. I. Les rentes hasseltoises. Bulletin de l'Institut Archéologique Liégeois, 52, 163-181.

Giammanco, R. (1959). La dottrina scolastica dell'usura. Nuova Rivista Storica, 63, 122-126.

Gómez Álvarez, J. U. (1977). El censo redimible y al quitar: un mecanismo real de transferencia de la propiedad. Estudis, 6, 5-25. 
González Ferrando, J. M. (2012). La idea de usura en la España del siglo XVI: consideración especial de los cambios, juros y asientos. Pecunia, 15, 1-57.

Grice-Hutchinson, M. (1982). El pensamiento económico en España (1177-1740), Barcelona: Crítica. La edición original en inglés, Early Economic Thought in Spain, 1177-1740, es de 1978.

Grunzweig, A. (1962). La garantie du crédit non-commercial dans la région de Paris au temps de Philippe le Bel. In Studi in onore di Amintore Fanfani (t. 2, pp. 527-545). Milán: A. Giuffrè editore.

Guerrieri, G. (1900). Gli ebrei a Brindisi ed a Lecce 1409-1497. Contributo alla storia dell'usura nell'Italia meridionale. Turín: F.lli Bocca.

Hernández Minano, J. de D. (1994-95). La condena de la usura y el comercio marítimo en los Emblemas Morales de S. de Covarrubias y en el sermonario cristiano de su época. Norba-arte, 14/15, 81-92.

Hernando, J. (1981). Realidades socioeconómicas en el Libro de las confesiones de Martín Pérez: usura, justo precio y profesión. Acta historica et archaeologica mediaevalia, 2, 93-106.

Hernando, J. (1982-83). El problema del crèdit i la moral a Catalunya (segle XIV). In La societat barcelonina a la Baixa Edat Mitjana (pp. 113-136). Barcelona: Universitat de Barcelona.

Hernando, J. (1983). Una obra desconeguda de Francesc Eiximenis: El Tractat d'usura. Acta histórica et archaeologica mediaevalia, 4, 129-148.

Hernando, J. (1984). El Tractat d'Usura de Francesc Eiximenis. Analecta Sacra Tarraconensia, 57/58, 5-100.

Hernando, J. (1989a). El tractat de Ramon Saera sobre la il.licitud del contracte de venda de violaris. Arxiu de textos catalans antics, 7/8, 241-253.

Hernando, J. (1989b). Quaestio disputatas de licitudine contractus emptionis et venditionis censualis cum contidione revenditionis: Un tratado sobre la licitud del contrato de compra-venta de rentas personales y redimibles. Bernat de Puigcercós, O.P. (siglo XIV). Acta historica et archaeologica mediaevalia, 10, 9-87.

Hernando, J. (1992). El contracte de venda de rendes perpètues i vitalícies (censals morts i violaris), personals i redimibles (amb carta de gràcia): el tractat d'autor anònim Pulchriores allegationes super contractibus censualium (segle XIV) - edició i estudi del text. Arxiu de textos catalans antics, 11, 137-179.

Hernando, J. (2000). De la usura al interés, crédito y ética en la baja Edad Media. In Aragón en la Edad Media. Sociedad, culturas e ideologías en la España bajomedieval (pp. 55-74). Zaragoza: Universidad de Zaragoza.

Hernando, J. (2007). Les controvèrsies teològiques sobre la licitud del crèdit a llarg termini. Barcelona. Quaderns d'bistória, 13, 213-238.

Herrera Bravo, R. (1987). La doctrina de la usura en la tradición romano-canónica europea. In J. Adame Goddard (Dir.), Estudios de derecho romano en honor de Álvaro D’Ors (pp. 451-482). Pamplona: Universidad de Navarra-EUNSA.

Hinojosa Montalvo, J. R. (1985). El préstamo judío en la ciudad de Valencia en la segunda mitad del siglo XIV. Sefarad, 45, 315-339.

Hinojosa Montalvo, J. R. (2009). El crédito judío en la Valencia medieval. In F. Sabaté y C. Denjean (Eds.), Cristianos y judios en contacto en la Edad Media: polémica, conversión, dinero y convivencia (pp. 205-264). Lleida: Milenio.

Hurtado Quero, M. (1987). Judíos de Ægreda: estudio de una familia de prestamistas a mediados del siglo XIV. Celtiberia, 37, 155-160.

Igual Luis, D. (2000). Los agentes de la banca internacional: cambistas y mercaderes en Valencia. Revista d'história medieval, 11, 105-138.

Igual Luis, D. (2003). La banca extranjera en la Corona de Aragón a finales de la Edad Media. In S. Claramunt (Ed.), El món urbà a la Corona d'Aragó del 1137 als decrets de Nova Planta (XVII Congrés d'História de la Corona d'Aragó. Barcelona. Poblet. Lleida, 2000) (pp. 401-418). Barcelona: Universitat de Barcelona. 
Igual Luis, D. (2014a). La circulación de capitales. El mundo financiero europeo en la Baja Edad Media. In F. Sabaté y M. Pedrol (Eds.), El mercat: un món de contactes i intercanvis: (Balaguer 2011) (pp. 201-226). Lleida: Pagès.

Igual Luis, D. (2014b). Letras de cambio de Cagliari a Valencia (1481-1499). Archivio Storico Sardo, 49, 207-306.

Igual Luis, D. (2016). Los Pintor, cambistas valencianos (1473-1488): una aproximación al significado de los rasgos informales de la economía. In P. Iradiel, G. Navarro, D. Igual, y C. Villanueva (Eds.), Identidades urbanas Corona de Aragón-Italia: redes económicas, estructuras institucionales, funciones políticas (siglos XIV$X V)$ (pp. 75-92). Zaragoza: Prensas de la Universidad de Zaragoza.

Igual Luis, D. (2018). Valencia, mercado de capitales: un ejemplo de giros dinerarios entre 1490 y 1492 , relacionados con Cerdeña. In D. Igual y G. Navarro (Eds.), El País Valenciano en la Baja Edad Media. Estudios dedicados al profesor Paulino Iradiel (pp. 211-232). Valencia: PUV.

Jover, G. (1995). Endeutament, desigualtat i despossessió pagesa. El cas de la parròquia de Petra 1443-1524 (Mallorca). Recerques, 33, 9-32.

Jover, G. (1997). Societat rural i desenvolupament economic a Mallorca: feudalisme, latifundi i pagesia, 1500-1800. Barcelona: Universitat de Barcelona.

Ladero Quesada, M. A. (1990-1991). Crédito y comercio de dinero en la Castilla medieval. Acta Historica et Archeologica Medievalia, 11-12, 145-159.

Ladero Quesada, M. A. (1975). Un préstamo de los judíos de Segovia y Ávila para la guerra de Granada, en el año 1483. Sefarad, 35, 151-157.

Lafuente, M. (2019). La deuda pública en el municipio de Zaragoza en la Baja Edad Media: el concejo de la ciudad y la corporación de propietarios de La Almozara. In P. Cateura y Ll. Tudela (Eds.), La crisi baixmedieval a la Corona d'Aragó (1350-1450) (pp. 213-231). Palma: Illa edicions.

Laliena, C. y Iranzo, M. T. (2016). Mercado de crédito, deuda censal y señoríos en la Corona de Aragón (siglo XV). In C. Laliena y M. Lafuente (Eds.), Consumo, comercio y transformaciones culturales en la Baja Edad Media: Aragón, siglos XIV-XV (pp. 233-264). Zaragoza: Universidad de Zaragoza.

Laliena, C. (2014). Crisis tempranas de la deuda municipal en el Bajo Aragón: Monroyo, 1346. In J. Á. Sesma y C. Laliena (Eds.), De la escritura a la historia (Aragón, siglos XIII-XV) (pp. 147-173). Zaragoza: Universidad de Zaragoza-CEMA.

Lapeyre, H. (1949). Les finances de Charles Quint. Annales, 4, 457-462. En realidad una reseña del libro de Carande, con quien publicaría más tarde un artículo conjunto sobre las relaciones comerciales en el Mediterráneo

Lapeyre, H. (1950). Doctrina y práctica bancaria en la Edad Media. Anales de Economía, 10, 181-197.

Lapeyre, H (1955). Los orígenes del endoso de letras de cambio en España. Moneda y crédito. Revista de economía, 52, 3-19.

Lapeyre, H. (1961). Alphonse V et ses banquiers. Le Moyen Âge, 67, 93-136.

Lapeyre, H. (1968). Contribution à l'histoire de la lettre de change en Espagne du XIVe au XVIIIe siècle. Anuario de bistoria económica y social, 1, 107-126.

Lapeyre, H. (1969). Une lettre de change castillane au début du XVe siècle. Revue internationale de l'histoire de la banque, 2, 245-246.

Lapeyre, H. (1973). La Taula de Canvis dans le cadre de l'histoire générale de la Banque. In Primer Congreso de Historia del País Valenciano (t. 1, pp. 175-186). Valencia: Universidad de Valencia.

Lara Izquierdo, P. (1983). Fórmulas crediticias medievales en Aragón: Zaragoza, centro de orientación crediticia (1457-1486). Jerónimo Zurita, cuadernos de historia, 45/46, 7-90.

Le Bras, G. (1923-1946). Art. Usure. La doctrine ecclésiastique de l'usure à l'époque classique (XIIe-XVe). In J. M. Vacant (Dir.), Dictionnaire de théologie catholique (pp. 2-336-2.372). París: Letouzey et Ané. 
Lefebvre, Ch. (1914). Observations sur les rentes perpétuelles dans l'ancien droit français. Nouvelle revue historique de droit français et étranger, 38, 105-135, 184-229.

Legras, H. (1911). Le bourgage de Caen. Tenure à cens et tenure à rente (XIe-XVe siècles). París: Arthur Rousseau, éditeur.

Lionti, F. (1884). Le usure presso gli ebrei. Archivio Storico Siciliano, 9, 195-212.

Llop Catalá, M. (1988). Observaciones socioeconómicas en la predicación de san Vicente Ferrer. Escritos del Vedat, 18, 201-240.

Llop Catalá, M. (1995). San Vicente Ferrer y los aspectos socioeconómicos del mundo medieval, Valencia: Ayuntamiento de Valencia.

Llop i Jordana, I. (1998). L'economia dels jueus de Vic al segle XV a través del préstec: el Liber Judeorum, 1341-1354. Barcelona: Universitat de Barcelona.

López Elum, P. (1971). Datos sobre la usura en Navarra en los comienzos del siglo XV. Príncipe de Viana, 32, 257-262.

López Rodríguez, C. (2005). Nobleza y poder politico en el Reino de Valencia (1416-1446). Valencia: PUV. Luzzatto, G. (1958), Tassi d'interesse e usura a Venezia nei secoli XIII-XV. In Miscellanea in onore di Roberto Cessi (t. I, pp. 191-202). Roma: Edizioni di Storia e Letteratura.

McCloskey, D. N. (2013). The poverty of Boldizzoni. Resurrecting the German Historical School. Investigaciones de Historia Económica, 9/1, 2-6, que alude al subtítulo de la edición inglesa del libro de Boldizzoni: Resurrecting Economic History.

McLaughlin, T. P. (1939-40). The teaching of the canonists on usury. Mediaeval Studies, 1, 81-147, y 2, $1-22$.

Maíz Chacón, J. (2009). Els mètodes crediticis jueus a la Mallorca medieval. In P. Cateura (Ed.), El créditi elsistema financer del Regne de Mallorca (segles XIV-XV) (pp. 147-164). Palma: Universitat de les Illes BalearsConsell Insular de Mallorca.

Martí Arau, A. (2010). Governar el deute en temps de crisi: Castelló d'Empúries (1386-1421). Anuario de Estudios Medievales, 40, 129-179.

Martí Arau, A. (2013). Origen y evolución de la deuda a largo plazo en una villa señorial catalana: Castelló d'Empúries (1344-1381). In C. Villanueva, D. A. Reinaldos, J. Maíz e I. Calderón (Eds.), Actas VI Simposio de Jóvenes Medievalistas (Lorca, 2012) (pp. 65-78). Murcia: Editum-SEEM.

Martí Arau, A. (2018).Pagar el deute propi i el del General: el cas de Castelló d'Empúries (1371-1372). Renda feudal i fiscalitat a la Catalunya baixmedieval: estudis dedicats a Manuel Sánchez Martinez (pp. 321-366). Madrid: CSIC.

Mas, A. (2008). Endeutament pagès i alienació de la terra a Mallorca durant la segona meitat del segle XV: l'exemple del terme de Maria de la Salut. Boletín de la Sociedad Arqueológica Luliana, 64, 89-112.

Matés Barco, J. M. y Tirapu Martínez, D. (1993). Crédito y usura en la legislación medieval: Los judíos de Navarra en los siglos XIII y XIV. Ius canonicum, 65, 379-396.

Mateu Boada, E. (2001). Aproximació als préstecs jueus de Tortosa: la figura de Bafaya Aquiva (segle XIV). Recerca, 5, 121-140.

Matilla Tascón, A. (1952). Declaratorias de los Reyes Católicos sobre reducción de juros y otras mercedes, Madrid: Servicio de Estudios de la Inspección General del Ministerio de Hacienda.

Mayol Llompart, A. (2009). De l'origen del deute públic a la crisi financera. Alcúdia i les estratègies inòqües de reducció del deute (1350-1460). In Pau Cateura (Ed.), El crédit i el sistema financer del Regne de Mallorca: (segles XIV-XV) (pp. 41-64). Palma: Universitat de les Illes Balears-Consell Insular de Mallorca.

Mayol Llompart, A. (2015). El crèdit privat a Pollença baix el sedàs de la cúria reial (1350-1399). In P. Cateura, J. Maíz y Ll. Tudela (Eds.), Inversors, banquers i jueus. Les xarxes financeres a la Corona d'Aragó (s. $X I V-X V)$ (pp. 81-108). Palma: Edicions Documenta Balear. 
Mercader, A. y Cateura, P. (2015). La 'Taula de Canvi municipal' entre 1401 y 1405 (en el reino de Mallorca). In P. Cateura, J. Maíz y Ll. Tudela (Eds.), Inversors, banquers i jueus. Les xarxes financeres a la Corona d'Aragó (s. XIV-XV) (pp. 121-136). Palma: Edicions Documenta Balear.

Miquel, L. (2019). La estructura del primer banco público de Europa: la Taula de Canvi de Barcelona (siglo XV). Medievalismo, 29, 297-321.

Mira Jódar, A. J. (1993). Els diners dels jueus: activitats econòmiques d'una família hebrea al món rural valencià. Revista d'história medieval, 4, 101-126.

Mira Jódar, A. J. (1997). Las finanzas del municipio: gestión económica y poder local; Sueca (s. XV-XVI). Valencia: Diputació de València.

Miranda García, F. (2000). La familia Bergerac y el crédito rural navarro en el siglo XIV. Revista de la CECEL, 1, 105-120.

Moeder, M. (1953). Rentes et prêts à Mulhouse au Moyen Âge. Revue d'Alsace, 92, 133-138.

Morelló, J. (2001). Fiscalitat i deute públic en dues viles del Camp de Tarragona: Reus i Valls, segles XIV$X V$. Barcelona: CSIC.

Morelló, J. (2002). El deute exterior mallorquí. Els creditors catalans a partir de l'estudi d'un capbreu de censals del segon quart del segle XV. Mayurqa, 28, 249-270.

Morelló, J. (2007). Els creditors barcelonins i la gestió del deute públic de Mallorca. Barcelona. Quaderns d'historia, 13, 313-350.

Morelló, J. (2009). El deute municipal a Eivissa. In P. Cateura (Ed.), El crèdit i el sistema financer del Regne de Mallorca (segles XIV-XV) (pp.79-100). Palma: Universitat de les Illes Balears-Consell Insular de Mallorca.

Morro Veny, G. (2006). Fiscalitat i deute públic en el regne de Mallorca (1385-1405). In P. Cateura (Ed.), Comprar, vendre i pagar al rei: els impostos indirectes al Regne de Mallorca, (segles XIV-XV); Palma de Mallorca, 2005 (pp. 45-70). Palma: El Tall.

Muntané Santiveri, J. X. (2013). El testament i l'inventari d'Astruc Iossef, jueu prestamista de Manresa (1391), seguits d'un inventari i un testament menors. Miscelánea judaica catalana, 5, 101-133.

Muntané Santiveri, J. X. (2016). Acords fiscals de prestadors jueus forasters en el Liber secretariorum aliame judeorum Minorise (Manresa, 1343-1346). Sefarad, 76, 251-288.

Muntaner Alsina, C. (2013). Crédito y endeudamiento vecinal en la Cataluña litoral (s. XIV): el caso de Sitges, una pequeña villa señorial. In C. Villanueva et al. (Eds.), Actas V Simposio de Jóvenes Medievalistas (pp. 155-167). Murcia: Editum-SEEM.

Muñoz Pomer, M. R. (1987). Origenes de la Generalidad Valenciana. Valencia: Generalitat Valenciana.

Muñoz Pomer, M. R. (2013). La consolidación de la Generalidad valenciana: élites y deuda pública. In I. Falcón (Ed.), El compromiso de Caspe (1492), cambios dinásticos y constitucionalismo en la Corona de Aragón (pp. 560-569). Zaragoza: Diputación General de Aragón.

Navarro Gómez, R. (2009). Règim jurídic del deute públic en el regne de Mallorca (segles XIV-XV). In P. Cateura (Ed.), El crédit i el sistema financer del Regne de Mallorca: (segles XIV-XV) (pp. 171-183). Palma: Universitat de les Illes Balears-Consell Insular de Mallorca.

Navarro, G. e Igual, D. (2001). Mercaderes-banqueros en tiempos de Alfonso el Magnánimo. In XVI Congresso Internazionale di Storia della Corona d'Aragona (t. 1, pp. 949-967). Nápoles: Paparo edizioni.

Navarro, G. e Igual, D. (2002). La tesorería general y los banqueros de Alfonso Vel Magnánimo. Castellón: Sociedad Castellonense de Cultura.

Necoechea, R. C. (1989). Retirement made easy: Annuities in Medieval England. Los Ángeles: University of California.

Nelson, B. N. (1949). Blancardo (the jew?) of Genoa and the restitution of usury in medieval Italy. In Studi in onore di Gino Luzzatto (t. I, pp. 96-116). Milán: A. Giuffrè.

Magdalena Nom de Déu, J. R. (1988). Judios y cristianos ante la 'Cort del Justícia' de Castellón. Castellón: Diputació de Castelló. 
Magdalena Nom de Déu, J. R. (1977). Juramentos de prestamistas y corredores judíos en Castellón de la Plana (1441-1488). Anuario de filología, 3, 215-223.

Magdalena Nom de Déu, J. R., Casanovas Miró, J., Castells, M. y García, S. (1990). Libro de cuentas de un prestamista judio gerundense del siglo XIV. Barcelona: Universidad de Barcelona.

Noonan, J. T. (1957). The Scholastic Analysis of Usury, Cambridge, Mass.: Harvard University Press.

Olaso, V. (1987). L'endeutament censal a la vila de Gandia durant la Baixa Edat Mitjana. Ullal, 11, 51-64.

Oliveira Campos, R. (1952). Uma interpretação institucional das leis medievais da usura. Revista brasileira de economia, 6, 105-131.

Ortega Cervigón, J. I. (2010). La reducción de juros de 1480 de los Reyes Católicos y la nobleza conquense. En la España medieval, 33, 131-140.

Ortí, P. (2009). La deuda pública municipal en una pequeña ciudad del nordeste catalán: Sant Feliu de Guíxols durante la segunda mitad del siglo XIV. In M. Sánchez (Ed.), La deuda pública en la Cataluña bajomedieval (pp. 101-152). Madrid: CSIC.

Ourliac, P. (1960). La théorie canonique des rentes au début du XVe siècle. In Études historiques à la mémoire de Noël Didier (pp. 231-243). París: Éditions Montchrestien.

Pacaut, M. (1963). Saint Bernardin de Sienne et l'usure. Le Moyen Age, 69, 743-752.

Padrós, J. A. (1997). Els masos i el crèdit. Moments de l'endeutament a la vall d'en Bas (segle XVI). Recerques, 35, 7-25.

Palou Santandreu, J. (2000). El problema del deute públic i l'enfortiment del poder reial. Mayurqa, 26, 197-208.

Pardos Martínez, J. A. (1984). Hacienda municipal y constitución de rentas: 'censos' y deuda del concejo de Burgos, 1476-1510 ca. Anuario de Historia del Derecho Español, 54, 599-612.

Pastor Zapata, J. L. (1984). Censales y propiedad feudal. El Real de Gandía: 1407-1550. En la España medieval, 5, 735-766.

Pastor Zapata, J. L. (1992). Gandia en la Baixa Edat Mitjana: La vila i el senyoriu dels Borja. Gandia: CEIC Alfons el Vell.

Pastor Zapata, J. L. (1997). Patrimonio y endeudamiento de la nobleza valenciana en el siglo XV: los Ladró y su señorío de Thoris. In M. I. Loring García (Ed.), Historia social, pensamiento historiográfico y Edad Media: homenaje al prof. Abilio Barbero de Aguilera (pp. 431-447). Madrid: Ediciones del Orto.

Pastor Zapata, J. L. (2000). Els Borja, ducs de Gandia: implantació d'un llinatge i construcció d'un espai senyorial en el trànsit del segle XV al XVI. In Sucre \& Borja. La canyamel dels Ducs. Del trapiga la taula (pp. 169-200). Gandia: CEIC Alfons el Vell.

Pastor Zapata, J. L. (2010-11). Duques y barones: el patrimonio señorial de los Borja más allá de Gandía a fines del siglo XV. Revista Borja, 3, 19-46.

Pereira Iglesias, J. L. (2001). Valoraciones doctrinales sobre crédito, usura y moral de cambios en tiempos de Carlos V. In J. L. Castellano (Ed.), Carlos V: europeismo y universalidad (t. 4, pp. 499-538). Madrid: Sociedad Estatal para la Conmemoración de los Centenarios de Felipe II y Carlos V.

Pereira Iglesias, J. L. (1995). El préstamo hipotecario en el Antiguo Régimen. Los censos al quitar. Cádiz: Universidad de Cádiz.

Peset, M. (1982). Dos ensayos sobre la historia de la propiedad de la tierra. Madrid: Editoriales de Derecho Reunidas.

Petot, P. (1928). La constitution de rente aux XIIe et XIIIe siècles dans les pays coutumiers. Dijon: Publications de l'Université de Dijon.

Picazo Muntaner, A. (2007). Els conversos de Mallorca i els censals a particulars; còmputs, grups financers i distribució. Randa, 59, 37-44. 
Piles Ros, L. (1984) Situación económica de Valencia a comienzos del siglo XIV a través de los préstamos judaicos. In La società mediterranea all'epoca del Vespro. 11 Congresso di Storia della Corona d'Aragona (t. 4, pp. 63-88). Palermo: Accademia di Scienze, Lettere e Arti.

Platelle, H. (1966). Les rentes viagères et le problème de l'endettement à Saint-Amand au XVe siècle. Tijdschrift voor rechtsgeschiedenis, 34, 329-374.

Poirrier, Ph. (Ed.) (2012). La historia cultural: ¿un giro historiográfico mundial? Valencia: PUV.

Pons Alòs, V. (1995). El señorio de Sumacàrcer en la Baja Edad Media. De mudéjares a moriscos. Sumacàrcer: Associació d'Amics de l'Ermita de Sumacàrcer.

Postan, M. M. (1927-1928). Credit in medieval trade. The Economic History Review, 1, 234-261.

Rabinowitz, J. J. (1944). Some remarks on the evasion of the usury laws in the Middle Ages. The Harvard theological review, 37, 49-59.

Ramia de Cap, R. (1948). Notas sobre el crédito en España en la baja Edad Media. Anales de Economía, 8, 329-353.

Rebouis, H.-E. (1881). Essai sur l'origine et le développement du crédit, du change et de l'assurance avant le $X V$ e siècle. París: Positions des thèses de l'École des Chartes.

Reixach, A. (2018). Finances públiques i mobilitat social a la Catalunya de la Baixa Edat Mitjana: Girona, 1340-1440. Madrid: CSIC.

Reglero de la Fuente, C. M. (2020). Crédito, acreedores y deudores en un pueblo castellano: Castrillo Tejeriego (1334-1335). Anuario de Estudios Medievales, 50, 353-381.

Rich Abad, A. (1991). Els jueus de Barcelona a través del préstec, 1370-1380. In Primer col.loqui d'història dels jueus a la Corona d'Aragó (pp. 439-447). Lleida: Institut d'Estudis Ilerdencs.

Riera, J. (1993). Jafudà Alatzar, jueu de València (segle XIV). Revista d'história medieval, 4, 65-100.

Romano, D. (1988). Prestadores judíos en los estados hispánicos medievales. Estudios mirandeses, 8, 117-126.

Romano, D. (1996). El estatuto de Huesca (1307) sobre la usura judía. In XV Congreso de Historia de la Corona de Aragón, 1: El poder real en la Corona de Aragón, siglos XIV-XVI (t. I, 5, pp. 257-272). Zaragoza: Gobierno de Aragón.

Romano, D. (1994). Los judíos hispánicos y el préstamo. In D. Assaf (Ed.), Proceedings of the Eleventh World Congress of Jewish Studies (Jerusalem, 1993) (pp. 91-98). Jerusalén: World Union of Jewish Studies.

Roustit, Y. (1954). La consolidation de la dette publique à Barcelone au milieu du XIVe siècle. Estudios de Historia Moderna, IV, 15-156.

Rubio Manuel, D. (2003). El crèdit a llarg termini a Barcelona a la segona meitat del segle XIV: els censals morts $i$ els violaris. Universitat de Barcelona, tesis doctoral inédita.

Rubio Martínez, A. (2010). Las cartas declaratorias de Toledo. La reducción de juros y mercedes aplicada a la nobleza y aristocracia gallega. Boletín de la Real Academia de la Historia, 207, 95-139.

Ruiz Gómez, F. (1987). Usura judía y préstamo eclesiástico; contribución al estudio de los orígenes del censo al quitar en Castilla. In F. Ruiz Gómez y M. Espada Burgos (Dir.), Encuentros en Sefarad. Actas del congreso internacional "Los judios en la historia de España"(pp. 71-102). Ciudad Real: Instituto de Estudios Manchegos.

Ruiz Torres, P. (2002). De la síntesis histórica a la historia de Annales. La influencia francesa en los inicios de la renovación historiográfica española. In La historiografía francesa del siglo XX y su acogida en España: coloquio internacional (pp. 83-105). Madrid: Casa de Velázquez.

Sadourny, A. (1971). Les rentes à Rouen au XIIIe siècle. Annales de Normandie, 21, 99-108.

Salvioli, G. (1906). La dottrina dell'usura secondo i canonisti e i civilisti italiani dei secoli XIII e XIV. In Studi giuridici in onore di Carlo Fadda pel XXV anno del suo insegnamento (t. 2, pp. 259-278). Nápoles: Luigi Pierro. 
Sánchez Martínez, M. (2003), Deuda pública, monarquía y ciudades en los países de la Corona de Aragón (siglos XIV y XV). In M. Sánchez Martínez (Ed.), Pagar al rey en la Corona de Aragón durante el siglo XIV: (estudios sobre fiscalidad y finanzas reales y urbanas) (pp. 523-562). Barcelona: IMF-CSIC.

Sánchez Martínez, M. (2006a), La Corona en los orígenes del endeudamiento censal de los municipios catalanes (1343-1344). In D. Menjot y M. Sánchez (Eds.), Fiscalidad de Estado y fiscalidad municipal en los reinos hispánicos medievales (pp. 239-274). Madrid: Casa de Velázquez.

Sánchez Martínez, M. (2006b). El mundo del crédito en la Corona de Aragón. In A. Pérez y G. Cruz (Eds.), Hijos de Mercurio: banqueros, prestamistas, usureros y transacciones comerciales en el mundo mediterráneo (pp. 343-374). Madrid: Ediciones Clásicas.

Sánchez Martínez, M. (2007). Algunas consideraciones sobre el crédito en la Cataluña medieval. Barcelona. Quaderns d'historia, 13, 9-26.

Sánchez Martínez, M. (Ed.) (2009a). La deuda pública en la Cataluña bajomedieval, Madrid: CSIC.

Sánchez Martínez, M. (2009b). Las primeras emisiones de deuda pública por la Diputación del General de Cataluña (1365-1369). In M. Sánchez Martínez (Ed.), La deuda pública en la Cataluña bajomedieval (pp. 219-258). Madrid: CSIC.

Sánchez Martínez, M. (2013). Barcelona, mercado de la deuda pública emitida por la Diputación del General de Cataluña (1371-1374). In M. Sánchez Martínez(Ed.), Al'entorn de la Barcelona medieval: estudis dedicats a la Doctora Josefina Mutgé i Vives (pp. 413-442). Barcelona: CSIC.

Sánchez Martínez, M. (2019). El parlamento de Vilafranca de 1353: deuda pública, sistema fiscal municipal y vertebración urbana en Cataluña. In M. I. del Val Valdivieso, J. C. Martín Cea y D. Carvajal de la Vega (Eds.), Expresiones del poder en la Edad Media: homenaje al profesor Juan Antonio Bonachia Hernando (pp. 625-634). Valladolid: Universidad de Valladolid.

Sánchez Martínez, M. y Furió, A. (Eds.) (1996). Col.loqui Corona, municipis i fiscalitat a la baixa edat mitjana. Lleida: Institut d'Estudis Ilerdencs.

Santamaría, A. (1972-73). La deuda pública en la parte foránea, al finalizar el siglo XV. Anuario de Estudios Medievales, 8, 259-304.

Sapori, A. (1929). L'usura nel Dugento a Pistoia. Studi Medievali, 2, 208-216.

Sayous, A.-E. (1932). Les opérations des banquiers italiens en Italie et aux foires de Champagne pendant le XIIIe siècle. Revue historique, 170, 1-31.

Sayous, A.-E. (1933). L'origine de la lettre de change: les procédés de crédit et de paiement dans les pays chrétiens de la Méditerranée occidentale entre le milieu du XIIe siècle et celui du XIIIe siècle. Revue historique de droit français et étranger, 12, 60-112.

Sayous, A.-E. (1934a). Note sur l'origine de la lettre de change et les débuts de son emploi à Barcelone (XIVe siècle). Revue historique de droit français et étranger, 13, 315-322.

Sayous, A.-E. (1934b). Le rôle du capital dans la vie locale et le commerce extérieur de Venise entre 1050 et 1150. Revue belge de philologie et d'histoire, 13, 657-696.

Schnapper, B. (1957). Les rentes au XVIe siècle: histoire d'un instrument de crédit. París: SEVPEN.

Schnapper, B. (1965). Les rentes chez les théologiens et les canonistes du XIIIe au XVIe siècle. In Études d'histoire du droit canonique dédiées à Gabriel Le Bras (t. 2, pp. 965-995). París: Sirey.

Sesma Muñoz, J. Á. (1977). La Diputación del Reino de Aragón en la época de Fernando II: (1479 - 1516), Zaragoza: Institución Fernando el Católico.

Sicard, G. (1965). L'usure en milieu rural: notes sur le bail à cheptel dans la doctrine de la fin du Moyen Âge. In Études d'histoire du droit canonique dédiées à Gabriel Le Bras (t. 2, pp. 1.395-1.405). París: Sirey.

Sobrequés, J. (1973), Contribució econòmica del municipi de Barcelona a l'empresa de recuperació del regne de Mallorca per Pere el Cerimoniós (1343-1349). In VIII Congreso de Historia de la Corona de Aragón (t. III, pp. 291-302). Valencia: Caja de Ahorros y Monte de Piedad. 
Soldevila, X. (2014). Crédito y endeudamiento popular en el Ampurdán (ca 1300-1348). In M. Bourin, F. Menant y Ll. To Figueras (Eds.), Dynamiques du monde rural dans la conjoncture de 1300: échanges, prélèvements et consommation en Méditerranée occidentale (pp. 469-491). Roma: École française de Rome.

Somoza, T. (2014). Las intervenciones de los Reyes Católicos ante el endeudamiento campesino (Ávila, Siglo XV). Anuario del Centro de Estudios Históricos Prof. Carlos S. A. Segreti, 14, 93-108.

Speyer, O. (1883). Die ältesten Credit- und Wechselbanken in Frankfurt am Main 1402 und 1403. Frankfurt: Jaeger.

Stone, L. (1979). The revival of narrative: reflections on a new old history. Past and Present, 85, 74-94.

Stone, L. (1991). History and post-modernism. Past and Present, 131, 217-218.

Taeusch, C. F. (1942). The concept of 'usury'. Journal of the history of ideas, 3, 291-318.

Tello Hernández, E. (2015). La actividad crediticia de un hospital turolense a través de la compra de censales (1482-1517). Aragón en la Edad Media, 26, 293-320.

Todeschini, G. (1989). La ricchezza degli ebrei: merci e denaro nella riflessione ebraica e nella definizione cristiana dell'usura alla fine del Medioevo. Spoleto: Centro italiano di studi sull'alto Medioevo.

Todeschini, G. (2004). Ricchezza francescana: dalla povertà volontaria alla società di mercato, Bolonia: Il Mulino.

Todeschini, G., Quaglioni, D. y Varanini, G. M. (Eds.) (2005). Credito e usura fra teologia, diritto e amministrazione. Linguaggi a confronto (sec. XII-XVI). Roma: École française de Rome.

Torras Serra, M. (1996). El deute de la ciutat de Manresa l'any 1365. In Funcionament de les finances locals al llarg de la história (Actes del III Congrés Internacional d'História Local de Catalunya. Barcelona, 1995) (pp. 199-204). Barcelona: L’Avenç.

Torras Serra, M. (2018). El mercat de les rendes a la Manresa de finals del segle XV: censos i censals. In J. Morelló, P. Ortí y P. Verdés (Eds.), Renda feudal i fiscalitat a la Catalunya baixmedieval: estudis dedicats a Manuel Sánchez Martinez (pp. 367-416). Madrid: CSIC.

Tracy, J. D. (1985). A financial revolution in the Habsburg Netherlands. Renten and renteniers in the county of Holland 1515-1565. Berkeley: University of California Press.

Urgell, R. (1996). Dinàmica del deute públic a la Universitat de Mallorca en el segle XV. In M. Sánchez y A. Furió (Eds.) Col.loqui Corona, municipis i fiscalitat a la baixa edat mitjana (pp. 675-701). Lleida: Institut d'Estudis Ilerdencs.

Urgell, R. (2009). El deute públic del regne de Mallorca entre 1435 i 1450. In P. Cateura (Ed.), El créditi el sistema financer del Regne de Mallorca: (segles XIV-XV) (pp. 65-78). Palma: Universitat de les Illes BalearsConsell Insular de Mallorca.

Usher, A. P. (1931-32). Deposit banking in Barcelona, 1300-1700. Journal ofeconomic and business history, 4, 121-155.

Van Bavel, B. (2010a). Markets for land, labor, and capital in Northern Italy and the Low Countries, twelfth to the seventeenth century. The Journal of Interdisciplinary History, 41, 503-531.

Van Bavel, B. (2010b). Manors and markets: economy and society in the Low Countries, 500-1600, Oxford: Oxford University Press.

Van Bavel, B. (2016). The invisible hand? How market economies have emerged and declined since AD 500, Oxford: Oxford University Press.

Vázquez de Prada, V. (1990). La historia económica en España (1940-1989): esbozo de su nacimiento y desarrollo. Hispania, L/175, 473-487.

Verdés, P. (2004). "Per ço que la vila no vage a perdició": la gestió del deute públic en un municipi català (Cervera, 1387-1516). Barcelona: CSIC.

Verdés, P. (2007). Barcelona, capital del mercat del deute públic català, segles XIV-XV. Barcelona. Quaderns d'história, 13, 283-311. 
La Veu del Regne (2018). La Veu del Regne. Representació politica, recursos públics i construcció de l'Estat. 600 anys de la Generalitat valenciana, Valencia (actas en curso de publicación).

Vicens Vives, J. (17 de julio de 1954). Sobre el problema de la decadencia económica de Cataluña en el siglo XV. Destino. (Recogido en Obra dispersa. Catalunya, abir i avui. Barcelona: Vicens-Vives, 1967, pp. 464-467).

Vicens Vives, J. (1959). Manual de Historia Económica de España (cap. 22: Dinero, usura y hacienda en Castilla). Barcelona: Teide.

Viciano, P. (1989). Catarroja: una senyoria de l'Horta de Valéncia en l'época tardomedieval. Catarroja: Ajuntament de Catarroja.

Viciano, P. (1990). Ingrés i despesa d'una vila valenciana del Quatrecents: les finances municipals de Castelló de la Plana (1426-1427). Boletin de la Sociedad Castellonense de Cultura, 66, 635-664.

Viciano, P. (1991a), La gestió econòmica d'un monestir cistercenc femení: la Saïdia de València a la fi del segle XV. Revista d'história medieval, 2, 111-132.

Viciano, P (1991b). L'estratègia rendista del patriciat valencià: el censal i la terra en les inversions d'un mercader del segle XV. Afers: fulls de recerca i pensament, VI/11-12, 127-136.

Viciano, P. (1992). Fiscalitat local i deute públic al País Valencià. L'administració de la vila de Borriana a mitjan segle XV. Anuario de Estudios Medievales, 22/1, 513-533.

Viciano, P. (1993). La promoción social de una familia de mercaderes valencianos: los Miquel de Castellón en el siglo XV. Hispania, LIII/185, 971-986.

Viciano, P. (1995). Francesc Agramunt, un home de vila. In L'univers dels prohoms. Perfils socials a la València baix-medieval (pp. 175-215). Valencia: Tres i Quatre.

Viciano, P. (2008). Regir la cosa pública:prohoms ipoder local a la vila de Castelló (segles XIV-XV). Valencia: PUV.

Viciano, P. (2013). Endeudarse para consumir e invertir. La función económica de las obligaciones en una villa rural valenciana (Castellón de la Plana en 1499). Historia agraria, 61, 13-44.

Viciano, P. (2018a). Mercado cerealista, crédito a corto plazo y desigualdad económica en el reino de Valencia. Las villas de Cocentaina y Castellón en el siglo XV. Hispania, 78, 103-137.

Viciano, P. (2018b). Deute públic i renda censalista al País Valencià en el segle XV. Una proposta d'interpretació. Anuario de Estudios Medievales, 48/2, 925-953.

Vilar, P. (1979) Catalunya dins l'Espanya moderna, Barcelona: Edicions 62. (Edición original en francés, 1964-1968).

Villagrasa, D. (30 de septiembre de 2015). Moneda y crédito: la revista que nació en la autarquía y predijo el nacimiento del euro. El Imparcial.

Villalonga Serrano, J. L. (2007). Crisis y endeudamiento en la campiña sevillana a finales de la Edad Media. In R. H. Oliva y P. Benito (Eds.), Crisis de subsistencia y crisis agrarias en la Edad Media (pp. 331-357). Sevilla: Universidad de Sevilla.

Villegas Rodríguez, M. (1962). Miguel Bartolomé Salón, O.S.A., y su doctrina sobre el préstamo. Anuario jurídico y económico escurialense, 3, 313-429.

Woollen, C. J. (1940). A theory of Usury. Downside review, 58, 187-198.

Zuijderduijn, C. J. (2009). Medieval capital markets: markets for renten, state formation and private investment in Holland (1300-1550). Leiden y Boston: Brill.

\section{Notas}

1 El segundo y el tercer volumen del libro aparecerían en 1949 y 1967, publicados ambos por la Sociedad de Estudios y Publicaciones. En 1987, con motivo del centenario del nacimiento del autor, la obra fue reeditada por la editorial Crítica. 
2 El artículo de Bennassar, basado enteramente en documentación del Archivo Histórico Provincial de Valladolid, no contiene ninguna referencia bibliográfica española: todas son francesas, en particular, la gran obra de Bernard Schnapper sobre este instrumento de crédito (1957).

3 Castillo, antiguo asistente del CNRS y discípulo de Fernand Braudel, fue, en el curso 1966-1967, el primer profesor de historia económica en el Centro de Estudios Económicos de Valencia, precedente de la actual Facultad de Economía, de la Universidad de Valencia. Su obra como historiador está más centrada en la Edad Moderna.

4 Más recientemente, Fernando Andrés Robres (1987), que ha estudiado las estrategias inversoras del Colegio del Corpus Christi de Valencia, no parece encontrar en ellas un interés por expropiar a los campesinos, sino por adaptar sus rentas a las coyunturas del mercado,

5 En sus siguientes publicaciones Clavero adoptaría una aproximación más antropológica -es decir, más propia de la antropología económica que de la economía neoclásica- al tema (1991). La traducción francesa, publicada bajo el título La Grâce du Don (1996), contaría con una presentación de Jacques Le Goff.

6 Sobre el censo consignativo redimible o al quitar como mecanismo de transferencia de la propiedad agraria del deudor al acreedor, véase también Gómez Álvarez (1977).

7 He tomado la cita de Ladero (1990-1991), quien recoge también la opinión más matizada pero igualmente pesimista de Jean Gautier-Dalché sobre las capacidades de la economía castellana para el crédito, dada la ausencia de burguesías urbanas potentes y, también, el hecho de que este quedaba en parte en manos de los judíos y de mercaderes extranjeros (Dufourcq y Gautier-Dalché, 1983, p. 254).

8 Para Vicens, la burguesía catalana del siglo XV, "habiéndose hallado enriquecida por sus abuelos, no supo romper, generosa, los moldes de sus privilegios para que por sus fracturas se filtrase la nueva estirpe de empresarios, ni tener la gallardía de abrir sus brazos a los artesanos y a los remensas" (Vicens Vives, 1967, pp. 464-467).

9 La expresión 'strategia di conquista territoriale' fue acuñada por Ch. M. de la Roncière (1973, p. 66), pero el concepto, tanto con este mismo término o con otros, ha sido utilizado por muchos otros autores (Giuliano Pinto, Gabriella Piccinni, Lidia Calzolai, Paolo Pirillo, Giampaolo Francesconi...). 